\title{
Current and future groundwater withdrawals: Effects, management and energy policy options for a semi-arid Indian watershed
}

\author{
Rajendra P. Sishodia ${ }^{a, b}$, Sanjay Shukla ${ }^{b, *}$, Wendy D. Graham ${ }^{c}$, Suhas P. Wani ${ }^{\mathrm{d}}$, \\ James W. Jones ${ }^{\mathrm{e}}$, James Heaney ${ }^{\mathrm{f}}$ \\ a International Crops Research Institute for Semi-Arid Tropics (ICRISAT), Patancheru, Telangana 502324, India \\ ${ }^{\mathrm{b}}$ Agricultural and Biological Engineering (ABE) Department, SWFREC, University of Florida (UF), Immokalee, FL 34142, United States \\ ${ }^{c}$ University of Florida (UF) Water Institute and Agricultural and Biological Engineering (ABE) Department, University of Florida (UF), Gainesville, \\ FL 32611, United States \\ d International Crops Research Institute for Semi-Arid Tropics (ICRISAT), Patancheru, Telangana 502324, India \\ e Agricultural and Biological Engineering (ABE) Department, University of Florida (UF), Gainesville, FL 32611, United States \\ ${ }^{\mathrm{f}}$ Department of Environmental Engineering Sciences, University of Florida (UF), Gainesville, FL 32611, United States
}

\section{A R T I C L E I N F O}

\section{Article history:}

Received 11 June 2016

Revised 10 May 2017

Accepted 17 May 2017

Available online 18 May 2017

\section{Keywords:}

Agricultural power subsidy

Hard rock aquifer

Water-food-energy nexus

Water use efficiency

Water storage

Well drying

\section{A B S T R A C T}

Effects of future expansion/intensification of irrigated agriculture on groundwater and surface water levels and availability in a semi-arid watershed were evaluated using an integrated hydrologic model (MIKE SHE/MIKE 11) in conjunction with biophysical measurements. Improved water use efficiency, water storage, and energy policy options were evaluated for their ability to sustain the future (2035) increased groundwater withdrawals. Three future withdrawal scenarios (low $=20$, medium $=30$, high $=50$ wells $/ 100 \mathrm{~km}^{2} /$ year) based on the historical rate of growth of irrigation wells were formulated. While well drying from falling groundwater levels was limited to drought and consecutive below average rainfall years, under the current (2015) withdrawals, significant increases in frequency and duration (17-97 days/year) of well drying along with $13-26 \%(19-37 \mathrm{~mm}$ ) reductions in surface flows were predicted under the future withdrawals. Higher (27-108\%) energy demands of existing irrigation pumps due to declining groundwater levels and reduced hydroelectric generation due to decreased surface flows would create a vicious water-food-energy nexus in the future. Crop failure, one of the main causes of farmers' emotional distress and death in the region, is predicted to exacerbate under the future withdrawal scenarios. Shift to negative net recharge $(-63 \mathrm{~mm})$ and early and prolonged drying of wells under the high scenario will reduce the groundwater availability and negatively affect crop production in more than $60 \%$ and $90 \%$ of cropped areas in the Rabi (November-February) and summer (March-May) seasons, respectively during a drought year. Individual and combined demand (drip irrigation and reduced farm electricity subsidy) and supply (water storage) management options improved groundwater levels and reduced well drying by 55-97 days/year compared to business-as-usual management under the high scenario. The combined management (50\% drip conversion, 50\% reduction in subsidy, and enhanced water storage) mitigated well drying even during drought and consecutive below average rainfall years under the high scenario. A conservative economic evaluation for management options under the high scenario showed increases in crop production and per farmer annual profits by \$987-\$1397 during a drought year (average household income $=\$ 1520 /$ year). A scale-up of results showed that diverting $50 \%$ state power subsidy ( $\$ 6$ billion for 3-6 years) can almost entirely fund the conversion to drip irrigation ( $\$ 4.2$ billion) and water storage structures ( $\$ 2.9$ billion) and help meet the water supply demand of a $50 \%$ increase in irrigated area under the high scenario. Converting flood to drip irrigation in $50 \%$ of irrigated area under the high scenario can reduce the electric energy consumption $\left(7 \times 10^{6} \mathrm{Mwh} / \mathrm{year}\right)$ and carbon footprint (6000 Mt/year) of groundwater irrigation by $24 \%$ in the state. Management options considered can potentially create a sustainable water-food-energy nexus in the larger semi-arid hard rock region. Reducing the

\footnotetext{
* Corresponding author.

E-mail addresses: rpsishodia@gmail.com (R.P. Sishodia), sshukla@ufl.edu, tharwaii@yahoo.com (S. Shukla),wgraham@ufl.edu (W.D. Graham), s.wani@cgiar.org (S.P. Wani), jimj@ufl.edu (J.W. Jones), heaney@ufl.edu (J. Heaney).
} 
power subsidy will require a strong political will since it has been used as a tool to win the elections in India. Considering future agricultural intensification, timely interventions are needed to ensure the livelihood and well-being of millions of small- and medium-scale farmers that rely on low storage, hard rock aquifers in the semi-arid regions of the world.

(c) 2017 Elsevier Ltd. All rights reserved.

\section{Introduction}

Future growth in population, dietary changes and related intensification of irrigated agriculture will significantly affect the environment and natural resources globally (McLaughlin and Kinzelbach, 2015). The resulting impacts on the environment may vary depending on the contribution of expanded and intensified (increased inputs) agriculture towards meeting the increased food demand (Tilman et al., 2011). In the past, agricultural withdrawals have caused groundwater depletion, reduced surface flows, salt water intrusion, land subsidence, loss of springs and wetlands and water quality problems in many parts of the world (Konikow and Kendy, 2005; Wen and Chen, 2006; Rodell et al., 2009; Wada et al., 2010). Arid and semi-arid regions which rely heavily on groundwater are the hotspots for rapid groundwater depletion; these include Indian sub-continent, China, western United States, Middle East, Mexico and North Africa (Gleeson et al., 2012; Famiglietti, 2014). With more than 250 billion $\mathrm{m}^{3}$ of groundwater withdrawals each year, India is the global leader in groundwater use (Shah et al., 2007; AQUASTAT, 2010). There has been a consistent rise in number of irrigation wells since 1960 (Shah, 2009) and presently 91\% of the groundwater withdrawals are used for irrigation (CGWB, 2014). Agricultural intensification in the form of increased cropping intensity (multiple crops per year) and conversion from rainfed to irrigated agriculture is depleting the groundwater supply in India. The groundwater irrigation is increasing, especially in the southern Indian region where free agricultural electricity policy was introduced to promote irrigated agriculture and poverty alleviation. Limited groundwater recharge capacity of semi-arid southern India makes it particularly vulnerable to groundwater depletion and associated environmental and socio-economic problems.

Groundwater depletion is likely to increase in the future with an increase in groundwater withdrawals caused due to higher agricultural, industrial and domestic water demands in India (Briscoe and Malik, 2006; Addams et al., 2009). Under the "business as usual" scenario, Amarasinghe et al. (2007) projected $20 \%$ and $40 \%$ increase in groundwater withdrawals by 2025 and 2050 compared to the base year 2000, respectively. However, increased groundwater withdrawals are likely to be better supported in deep alluvial aquifers (e.g. Indo-Gangetic plains) as compared to the low storage hard rock aquifers found in central and south India. Special emphasis is needed on evaluating the effects of future groundwater withdrawals on groundwater recharge, availability and downstream surface flows in these hard rock aquifer regions. In a watershed scale $\left(58 \mathrm{~km}^{2}\right)$ study in south India, Dewandel et al. (2010) predicted that unless management changes are made present rate of increase in pumping will dry up most wells by 2012-2013.

Complex aquifer systems such as hard rock aquifers represent almost 20\% of global area (Richts et al., 2011) and 65\% (240 million ha) of India (Singhal, 2007; World Bank, 2010). Complex hydro-geology and recharge processes coupled with increasing groundwater withdrawals and changing land use makes the management of these aquifers a challenging task. The weathered fractured aquifers, found mainly in central and southern part of India, are highly prone to drought due to their low-storage capacity combined with high climatic variability. These aquifers are already experiencing groundwater declines due to increasing irri- gated area and related withdrawals (Massuel et al., 2007; CGWB, 2011; Sishodia et al., 2016). The problem is compounded by the ongoing free electricity policy in many states in this hard rock region such as Andhra Pradesh, Telangana and Tamil Nadu; beyond bringing additional area under irrigation, free electricity is also causing water wastage. Irregular and night-time electricity supply and use of automatic switches to trigger pumps cause the water to run unattended in the fields resulting in water wastage which contributes to shortage. Future increase in irrigated acreage may result in widespread groundwater declines, however the resulting impacts and management of groundwater levels have not been evaluated. Evaluation of effects of current and future withdrawals on groundwater levels needs to be followed by identification of management strategies that could provide sustainable irrigation supply to expanded irrigated areas for meeting increased food demand. In addition, identified management strategies should be capable to create a sustainable water-food-energy nexus in the region.

Studies in the hard rock region have been mainly focused on supply management such as runoff harvesting (Foster, 2012; Garg et al., 2012; Massuel et al., 2014; Shah 2008). Runoff harvesting has been shown to improve the water availability at watershed scale (Garg et al., 2012), however studies have shown that it does not enhance the water supply at basin scale (Kumar et al., 2008). At basin scale, downstream users may experience reduced water availability due to runoff capture in upstream areas (Bouman et al., 2011) resulting in no net increase in water supply. Furthermore, low rainfall and aquifer storage capacity may limit the watershed scale benefits (e.g. water stored and recharge) of runoff harvesting in this semi-arid hard rock region. Runoff harvesting efforts needs to be complimented with demand management strategies (e.g. power subsidy reduction and flood to drip irrigation conversion) to sustain future irrigation expansion. Empirical studies have identified energy subsidy as a potential driving factor for increased groundwater withdrawals in India (Shah et al., 2008; Badiani and Jessoe, 2013). This nexus has been field verified by Sishodia et al. (2016) who showed a causal relationship between electricity subsidy and declining groundwater trends in the hard rock region of South India. Economic studies in India have shown that changes in energy policy can help reduce the groundwater demand (Kumar et al., 2011; Badiani and Jessoe, 2013); however, the actual effects on water levels and availability have not been evaluated. A physically-based, field-verified hydrologic modeling approach, is needed to evaluate the actual effects of groundwater withdrawals as well as the demand and supply management strategies on current and future water availability to create a sustainable water-food-energy nexus in the region.

Few modeling studies (Dewandel et al., 2010; Surinaidu et al., 2013) have evaluated the effects of current and future groundwater withdrawals on groundwater recharge and availability in this hard rock region of India. However, these studies have been limited especially due to lack of integrated surface water-groundwater modeling which meant ignoring the effects on surface flows. Groundwater and surface water are inter-connected and need to be managed conjunctively (Famiglietti, 2014). As opposed to either primarily surface water (e.g. SWAT or HELP) or groundwater (e.g. MODFLOW) flow modeling, use of an integrated, physically based model such as MIKE SHE/MIKE 11 (Graham and Butts, 2005) is bet- 


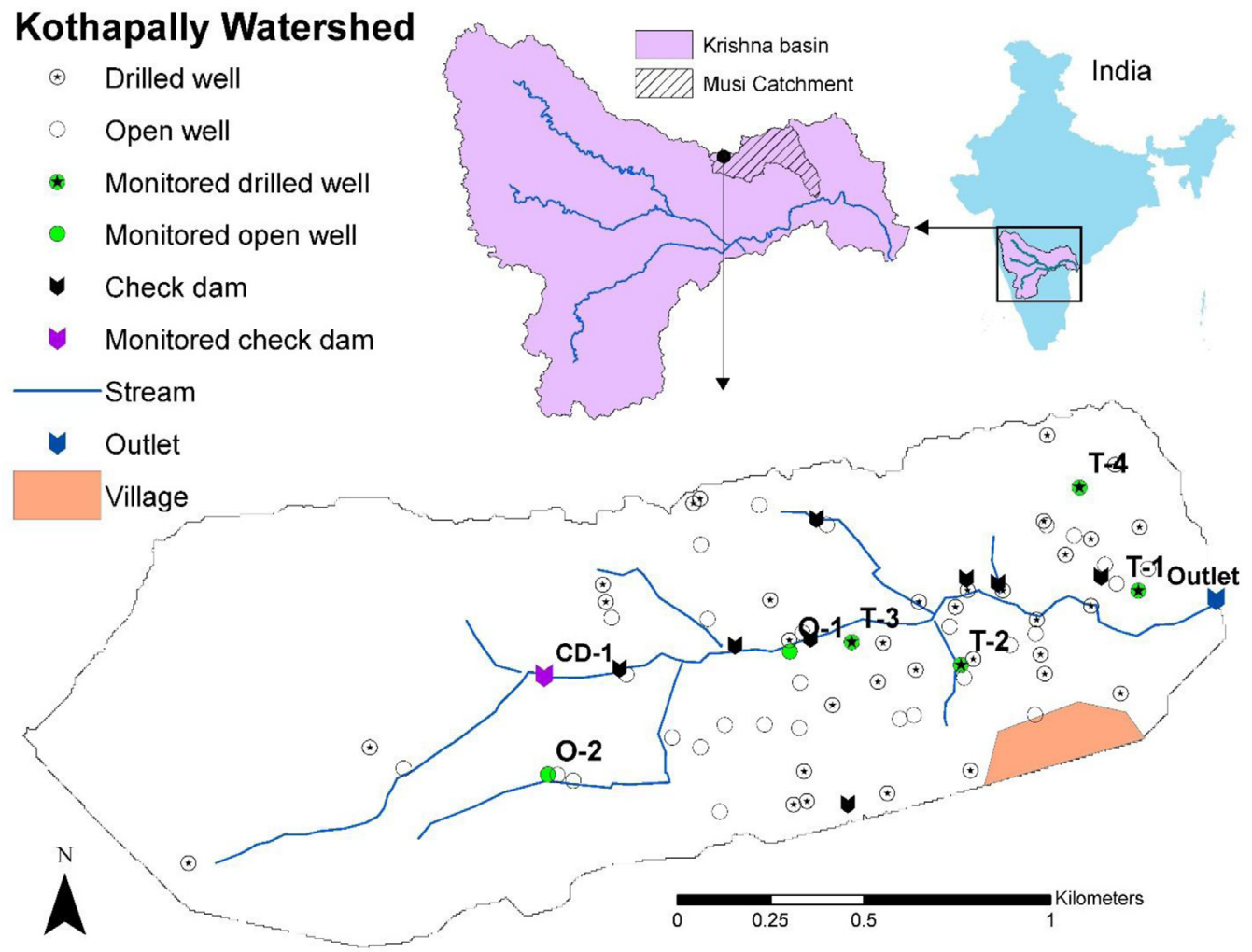

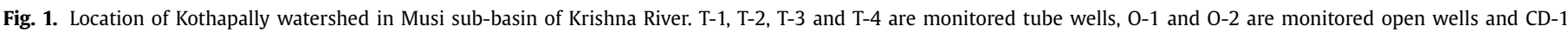
is the monitored in stream check dam.

ter suited for an accurate and realistic simulation of groundwater flow, recharge, levels as well as the changes in surface flows in response to different groundwater withdrawals and management, especially in multi-aquifer systems. MIKE SHE/MIKE 11 is one of the few integrated models which have shown to effectively work under different climate (arid to tropical) as well as hydrologic regimes (mountainous to costal and shallow to deep groundwater) to evaluate the water management, land use and climate change effects on groundwater and surface water flows (Demetriou and Punthakey, 1999; Jaber and Shukla, 2004; Im et al., 2009; Stoll et al., 2011; Wijesekara et al., 2012; Vansteenkiste et al., 2013). Integrated hydrologic model usually requires extensive long-term weather, soils, hydrogeology, land use, surface flows and groundwater levels data, which are only available in well-studied watersheds globally (Feyen et al., 2000; Jones et al., 2008). Many of these data, particularly long term sub-hourly to daily groundwater levels and surface flows, are not available for Indian watersheds (Adamowski et al., 2012). International Crops Research Institute for Semi-Arid Tropics (ICRISAT) has one such well-studied watershed in south India where additional data were collected for this study. We use long-term data and an integrated model in an agricultural watershed in semi-arid hard rock region of south India to 1) evaluate the effects of current and future groundwater withdrawals on surface and groundwater fluxes and availability, 2) evaluate demand and supply management strategies including state policies and their economics for sustainable groundwater use.

\section{Material and methods}

\subsection{Study site}

The Kothapally watershed (Fig. 1) is located at $17^{\circ} 22^{\prime} \mathrm{N}$ latitude $78^{\circ} 07^{\prime} \mathrm{E}$ longitude in semi-arid south Indian state of Telangana (former Andhra Pradesh). The watershed has an area of 290 ha and lies 600-640 $\mathrm{m}$ above mean sea level with an average slope of $1.3 \%$. It is a part of Musi river sub-basin which falls within the Krishna River basin. Average annual rainfall (2000-2014) for the watershed is $838 \mathrm{~mm}$ of which $85 \%$ falls during the monsoon season (June-October). Rainfall exhibits high inter-annual variability; for example annual rainfall during 2006-2009 varied from $484 \mathrm{~mm}$ in 2006-2007 to $1123 \mathrm{~mm}$ in 2008-2009. Here 2008-2009 refers to hydrological year (6/1/2008-5/31/2009), except noted otherwise. There are no perennial streams in the watershed and surface flow generally occurs during the monsoon season when enough runoff or baseflow is generated. Depending on the monsoon rainfall, high water table at the end of the monsoon can support baseflow until December-January. In 1999, ICRISAT started a pilot watershed development program in Kothapally (Fig. 1) where weather, crops, soil and hydrologic data collection was started in June 2012 to study the effects of groundwater withdrawals on surface flows and groundwater levels and to explore different management strategies to address water sustainability. Almost three-fourth of the watershed area is cropped during certain part of the year and the primary occupation of most households in the watershed is farming. Close proximity $(\approx 20 \mathrm{~km}$ ) to capital city of Hyderabad help farmers in the watershed and other surrounding area get good prices for fresh market vegetables and other products. Agriculture is one of the largest sectors in the state in terms of the gross domestic product and 55\% of the workforce depends on it (GOT, 2016).

\subsection{Hydrologic modeling}

MIKE SHE, originally developed from SHE (Système Hydrologique Européen) (Abbott et al., 1986a, b) is a distributed, physically based integrated hydrologic model that can simulate the land phase of hydrologic cycle. Main components of the MIKE SHE/MIKE 11 model include: evapotranspiration, overland flow, unsaturated zone, saturated zone and channel flow (MIKE11). Dy- 


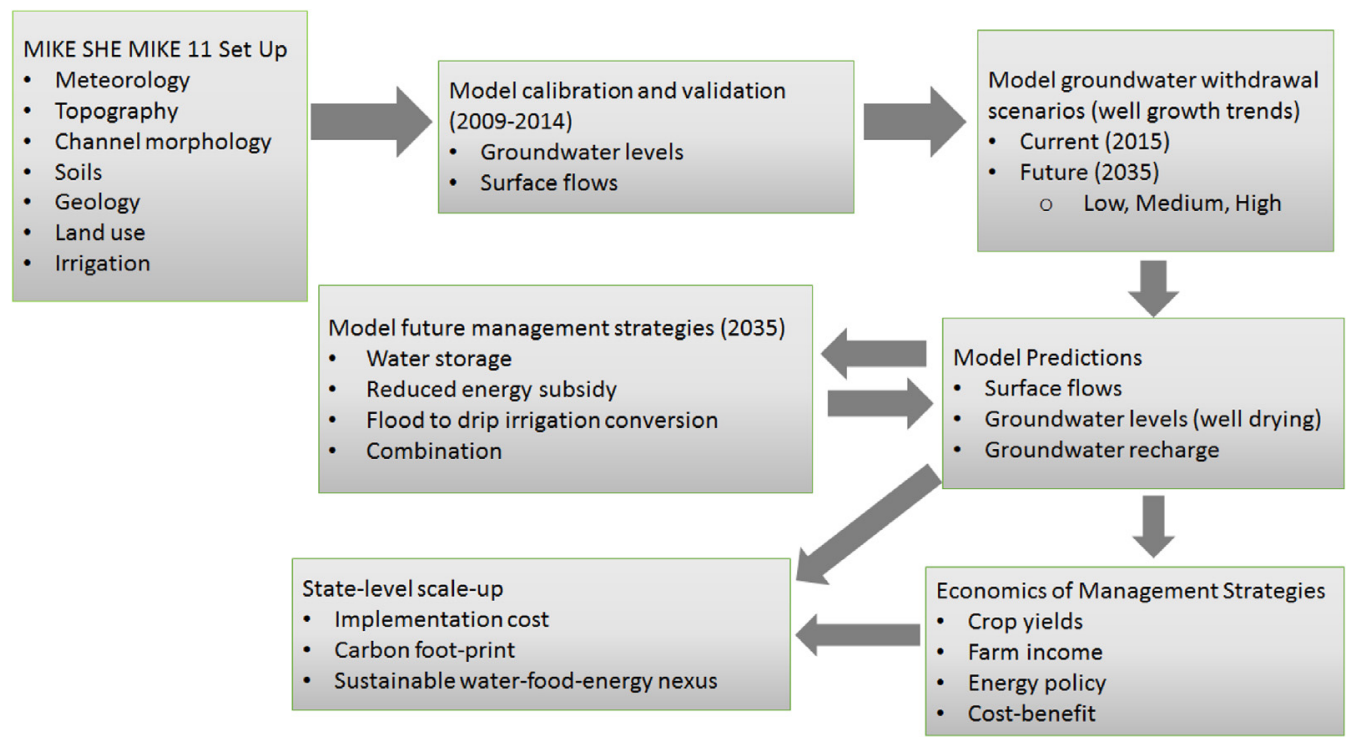

Fig. 2. Flow chart of methods followed in the study.

namic coupling of MIKE SHE with MIKE 11 allows for exchange of fluxes between MIKE 11 river channel and MIKE SHE overland, saturated and unsaturated zone components. The model estimates actual ET by Kristensen and Jensen method which uses crop coefficient $\left(\mathrm{K}_{\mathrm{c}}\right)$, Leaf Area Index (LAI), root depth (RD) and soil moisture. Fully dynamic finite difference solution of complete non-linear St. Venant equations in MIKE 11 is used to simulate the flow in open channels (Havnø et al., 1995; Jaber and Shukla, 2012). Overland flow is simulated by diffusive wave approximation of 2D Saint Venant equations. Unsaturated zone fluxes are simulated by fully implicit finite difference solution of 1-D Richards' equation while saturated zone flow is simulated by 3-D Darcy equations. Im et al (2009) reported that MIKE SHE may not accurately represent the runoff from paddy fields in Korea because it uses infiltration based approach to simulate the runoff however, the runoff from paddy fields depend on the height of the outlet which is frequently changed by the farmers during the growing season. This model limitation was not considered critical because paddy is grown in small area (3\%) of the watershed and the model performed well in simulating the watershed runoff.

The model was set up with $45 \times 45 \mathrm{~m}$ grid size which was considered to adequately represent the watershed with the available data set. A $45 \times 45 \mathrm{~m}$ grid closely represents the average size of typical farmers' fields. Topography of the watershed was generated with total station survey of the watershed covering more than 4200 survey points. Climatic, soil, geologic, stream network, land use, and irrigation data, collected during 2009-2014, were used to set-up the MIKE SHE/MIKE 11 model (Fig. 2). Model was calibrated and validated using measured surface and groundwater levels data. The field-verified model was used with future (2040-2069) rainfall, temperature and well growth projections (low, medium and high scenarios) to simulate the effects of climate change and irrigation expansion on ground water availability and surface flows. Several demand (energy subsidy, flood to drip irrigation conversion) and supply (rainfall-runoff storage) management options were evaluated in their ability to reduce the impacts of irrigation expansion and climate change on hydrologic extremes (well drying and flooding). A cost-benefit analysis of these management options was conducted (Fig. 2). A preliminary scale-up of the modeling and economic analyses results was carried out to assess the benefits of energy policy reforms.

\subsubsection{Meteorological and land use data}

Daily rainfall data were collected by an automatic weather station in the watershed installed in 2000. Rainfall data from a rain gauge located in the watershed were considered to adequately represent the rainfall in this relatively small watershed (290 ha). Hydrologic modeling studies in this semi-arid hard rock region have used similar or coarser resolution rainfall data (Garg et al., 2012; Perrin et al., 2012; Surinaidu et al., 2013). Reference ET, a required model input, was calculated using the "ET $T_{0}$ Calculator" software (http://www.fao.org/nr/water/eto.html) with the weather data obtained from weather station located at ICRISAT, Patancheru, Telangana (25 km from Kothapally) due to unavailability of solar radiation, humidly, wind speed and temperature data for the entire simulation period. Climatic parameters, except rainfall, are likely to be similar between ICRISAT and the watershed given their proximity, and geophysical and climatic homogeneity.

The land use map of watershed was prepared based on the farmer's survey, on-site visits, and satellite images. There are two main crop growing periods: Kharif (June-October, wet monsoon season) and Rabi (November-February, dry season). Some crops are also grown during summer (March-May, dry season) depending on water availability. About $56 \%$ of the watershed area was classified as rainfed cotton which is grown during June-December. The irrigated area comprised of $11 \%$ cotton-vegetable, $6 \%$ vegetablevegetable-vegetable, and 3\% paddy-vegetable. The remaining area (24\%) was classified as barren land.

\subsubsection{Irrigation and groundwater withdrawals}

Irrigation in the model was implemented based on the available moisture content in the soil except paddy-vegetable rotation. For the paddy-vegetable rotation, based on the farmers practice in the watershed, irrigation was applied at a rate of $7.2 \mathrm{~mm} /$ day and $3.2 \mathrm{~mm} /$ day for Paddy (Kharif) and vegetables (Rabi), respectively. For other crop rotations, MIKE SHE was configured to start the irrigation when available soil moisture (actual moisture minus wilting point) reached at $40 \%$ and $50 \%$ of maximum available moisture (saturation minus wilting point) during Kharif and Rabi season, respectively.

Irrigation withdrawals are a significant water balance component in the semi-arid settings however, because of lack of measured data it is commonly estimated using farmer surveys and sec- 
ondary data (Varalakshmi et al., 2012). Such estimations can introduce large uncertainty and transfer errors to other components (e.g. ET and groundwater storage) of the model. Irrigation withdrawals were measured in the field to reduce the uncertainty in model predictions. Flows from six open wells and 15 tube wells were measured with an ultrasonic flow meter (PORTAFLOW-C, Fuji Electric Co., Ltd., Tokyo, Japan) in November 2012. Tube wells are drilled deep and extend 40 to $100 \mathrm{~m}$ from the ground while open wells are shallow $(10 \mathrm{~m})$ and wide $(3-5 \mathrm{~m})$. Flow rates from open wells varied from 23 to $36 \mathrm{~m}^{3} / \mathrm{h}$ with an average of $27 \mathrm{~m}^{3} / \mathrm{h}$. Minimum and maximum measured flow rates from the tube wells were 6 and $27 \mathrm{~m}^{3} / \mathrm{h}$ with an average of $12.4 \mathrm{~m}^{3} / \mathrm{h}$. Such variability in pump flows or withdrawals can't be realized through farmer survey and thus provides an important insight into pumping differences in the watershed. The measured pump flows were used to set the maximum daily flow rates from the irrigation wells in the MIKE SHE. Groundwater level recorders, hereafter termed as level loggers (Solinst Levelogger, Solinist Canada Ltd., Ontario, Canada), were installed in seven wells to measure the groundwater levels on 15-min frequency during 2012-2014. Fluctuations in groundwater levels were used to determine the irrigation timings and duration. The groundwater level indicated an average of 700 and $200 \mathrm{~h}$ of annual pumping from tube wells and open wells, respectively. Pumping volume estimated from measured pumping hours and flow rates matched well with MIKE SHE simulated seasonal irrigation application in the watershed.

\subsubsection{Overland and river flow}

The MIKE SHE simulates runoff when ponding depth exceeds the detention storage in a model cell. Detention storage for natural and artificial local depressions, ponds and percolation tanks was estimated from storage structure dimensions. Seven in-stream water storage check dams in the watershed were represented as broad crested weirs in the MIKE 11 hydraulic model (Fig. 1). A specified head-discharge boundary condition was used at the main outlet weir. The channel leakage coefficient which governs the bidirectional flow exchange between stream and groundwater was determined through calibration (calibrated value $=3 \times 10^{-06} / \mathrm{s}$ ).

\subsubsection{Unsaturated zone}

The soils in the watershed are shallow to moderately deep (20 cm-2 m) predominantly Vertisols with clay to sandy clay loam texture. Soil samples from 50 locations (up to $1.5 \mathrm{~m}$ deep at seven locations) were collected in the watershed to characterize the soil texture, bulk density and estimate moisture retention at field capacity and wilting point in laboratory (Soilmoisture Equipment Corp, California, USA). The watershed was divided into eleven soil classes to capture the variability in soil depth and texture. Laboratory measured soil texture (\% sand, silt, clay), bulk density, field capacity and wilting point were used in ROSETTA (Schaap et al., 2001), a pedo-transfer function, to estimate the Van Genuchten (1980) model parameters and characterize soil moisture retention.

\subsubsection{Saturated zone}

Saturated zone component in MIKE SHE consisted of three layers; top weathered layer, middle compact layer and lower fractured layer extending up to $120 \mathrm{~m}$ depth below ground. Thickness of the upper weathered layer was assumed to be uniform $(14 \mathrm{~m})$ in the entire watershed. Based on the well log from local professional well drillers and consultations with farmers, the thickness of middle impermeable layer was estimated $(20-0.5 \mathrm{~m}$, with higher values in uplands). Highly heterogeneous nature of the weathered-fractured aquifer makes saturated hydraulic conductivity $\left(\mathrm{K}_{\mathrm{sat}}\right)$, specific yield $\left(\mathrm{S}_{\mathrm{y}}\right)$ and specific storage $\left(\mathrm{S}_{\mathrm{s}}\right)$ some of the most uncertain parameters in this semi-arid region (Singhal, 1997, 2007). Literature values (CGWB, 2007a, b, c; Dewandel et al., 2006;
Maréchal et al., 2006) of these parameters were used to define a plausible range, while the final values were determined through calibration. A no-flow boundary was used for all the computational layers in the saturated zone i.e. no exchange of fluxes between the watershed and surroundings. The presence of discontinuous fractures in the deeper layer promotes local or compartmentalized flow (Guihéneuf et al., 2014) and surface water boundary (e.g. basin or watershed) usually coincides with groundwater flow boundary in these aquifers (Limaye, 2010).

\subsection{Hydrologic data monitoring}

Measured groundwater levels in two shallow and four deep wells (2012-2014) and surface water levels behind a check dam (2012-2013) were used for calibrating and validating the model (Figs. 1 and 2). The 15-min level logger data showed that water levels in the tube wells rise back to a stable level within 3-4 h after pumping. Farmers in the watershed don't run their pumps for more than $6-7 \mathrm{~h}$ in a day because the electricity is available for a maximum of $6-7 \mathrm{~h}$ daily. Measured groundwater depth indicates that daily maximum levels in the wells would reasonably represent the daily natural groundwater levels; therefore, the model was calibrated against daily maximum observed groundwater levels in monitoring wells. Measured daily surface water levels, at the watershed outlet during 2009-2014, were used to estimate surface flows for model validation.

\subsection{Model calibration and validation}

Calibration parameters were selected based on the sensitivity analysis, hydrologic measurements, and literature review (Jaber and Shukla, 2012) (Table 1). Simulated groundwater heads in monitored wells were highly sensitive to soil $\mathrm{K}_{\mathrm{sat}}$. Other parameters such as $S_{s}$ and $S_{y}$ also significantly affected the groundwater heads, although to lesser degree than soil $\mathrm{K}_{\text {sat }}$. MIKE11 channel leakage coefficient and horizontal hydraulic conductivity $\left(\mathrm{K}_{\mathrm{h} \text {-sat }}\right)$ of the upper weathered layer were the most sensitive parameters affecting the simulated surface-water level behind the check dam (Table 1). The soil $\mathrm{K}_{\text {sat }}$ was calibrated first and other parameters namely $S_{s}, S_{y}$, saturated zone horizontal and vertical hydraulic conductivity ( $K_{\mathrm{h} \text {-sat }}$ and $\left.\mathrm{K}_{\mathrm{v} \text {-sat }}\right)$ and channel leakage coefficient were adjusted one at a time to achieve the best match between simulated and observed groundwater and surface water levels.

Model performance was evaluated with Nash Sutcliffe Efficiency (NSE), Root Mean Square Error (RMSE), Index of Agreement (d) and percent bias (PBIAS). The NSE (Nash and Sutcliffe, 1970) value indicates how well the observed versus simulated data plot fits a 1:1 line. RMSE is another widely used model performance criteria and indicates average error in model prediction. The index of agreement (d) (Willmott, 1981) measures the degree of model prediction error and varies between 0 and 1 . The PBIAS measures the average tendency of the simulated values to be larger or smaller than observed values (Gupta et al., 1999). In this study, model performance was rated based on the Moriasi et al. (2007) where NSE values between 0.65 and 0.75 indicates "good" model performance while NSE values greater than 0.75 indicates "very good" model performance.

\subsection{Groundwater withdrawal scenarios}

The calibrated and validated MIKE SHE/MIKE 11 model (20092014) was used to simulate current (2015) and future (2035) groundwater withdrawal scenarios with 14 years (2000-2014) of meteorological time series (Fig. 2). Historical growth of tube wells in the watershed, district and state (DES, 2004, 2013a) was used to develop an envelope of well growth rates for the next 20 
Table 1

MIKE SHE/MIKE 11 model parameterization for the Kothapally watershed.

\begin{tabular}{|c|c|c|c|}
\hline Parameter & Value or range & & Source \\
\hline Saturated soil hydraulic conductivity (m/sec) & $1 \times 10^{-7}-5 \times 10^{-6}$ & & Calibrated \\
\hline $\begin{array}{l}\text { Saturated and residual soil moisture contents } \\
\left(\theta_{\mathrm{s}} \text { and } \theta_{\mathrm{r}}\right)\end{array}$ & $\begin{array}{l}\theta_{\mathrm{s}}=0.45-0.55 \\
\theta_{\mathrm{r}}=0.06-0.09\end{array}$ & & $\begin{array}{l}\text { Estimated from ROSETTA (Schaap et al., } \\
\text { 2001) }\end{array}$ \\
\hline Van-Genuchten model soil parameters & $\begin{array}{l}\alpha=0.002-0.03 \\
\mathrm{n}=1.13-1.91 \\
\mathrm{l}=-1.34-0.50\end{array}$ & & $\begin{array}{l}\text { Estimated from ROSETTA (Schaap et al., } \\
\text { 2001) }\end{array}$ \\
\hline $\begin{array}{l}\text { Leaf Area Index (LAI), Root Depth (RD) (mm) } \\
\text { and Crop coefficient Kc }\end{array}$ & $\begin{array}{l}\text { Cotton (Maximum) } \\
\text { Vegetable (Maximum) }\end{array}$ & $\begin{array}{l}\text { LAI }-3.5 \\
\text { RD }-900 \mathrm{~mm} \\
\mathrm{~K}_{\mathrm{c}}-1.05 \\
\mathrm{LAI}-2.5 \\
\mathrm{RD}-500 \\
\mathrm{~K}_{\mathrm{c}}-1.1\end{array}$ & $\begin{array}{l}\text { Literature (Allen et al., 1998; Al-Khafaf } \\
\text { et al., 1978; Bland, 1993; Mohan and } \\
\text { Arumugam, 1994) }\end{array}$ \\
\hline Manning's number for overland flow $(M=1 / n)$ & 8 & & Garg et al. (2012) \\
\hline $\begin{array}{l}\text { Saturated zone layers hydraulic conductivity } \\
(\mathrm{m} / \mathrm{sec}) \text { - Horizontal and vertical }\end{array}$ & $\begin{array}{l}\text { Top weathered }-5 \times 10^{-5} \text { and } 4 \times 10^{-6} \\
\text { Middle impermeable }-5 \times 10^{-9} \text { and } 5 \times 10^{-9} \\
\text { Lower fractured }-3 \times 10^{-5} \text { and } 3 \times 10^{-6}\end{array}$ & & Calibrated \\
\hline Specific yield & $\begin{array}{l}\text { Top weathered - } 0.02 \\
\text { Middle impermeable }-0.001 \\
\text { Lower fractured - } 0.0015\end{array}$ & & Calibrated \\
\hline Specific storage $(1 / \mathrm{m})$ & $\begin{array}{l}\text { Top weathered }-3 \times 10^{-5} \\
\text { Middle impermeable }-1 \times 10^{-6} \\
\text { Lower fractured }-2.6 \times 10^{-5}\end{array}$ & & Calibrated \\
\hline $\begin{array}{l}\text { Leakage coefficient for river-aquifer exchange } \\
\text { (per second) }\end{array}$ & $3 \times 10^{-6}$ & & Calibrated \\
\hline
\end{tabular}

years in the watershed. Three scenarios, representing the observed ranges of growth rates in tube wells, were considered; 1) low (20 wells $/ 100 \mathrm{~km}^{2} /$ year) represents a conservative scenario, 2) medium ( 30 wells $/ 100 \mathrm{~km}^{2} /$ year) represents an average growth scenario while 3 ) high (50 wells $/ 100 \mathrm{~km}^{2} /$ year) represents an aggressive growth scenario (Fig. 2). Although the high scenario could be considered as "worst case scenario", it actually represents the observed well growth rate in the last 10 -year period in the watershed.

Future land use in MIKE SHE/MIKE 11 was developed by increasing the irrigated area to match the growth in number of tube wells. Irrigated area was increased by replacing the unirrigated cotton and barren land with irrigated crop rotations (e.g. cottonvegetable). Sishodia et al. (2016) have reported a decline in well yield or area irrigated per well with increasing well density in the region during 1993-2007. Therefore, each new well was set to irrigate1-1.1 ha of crop area in the dry season instead of 1.2-1.6 ha under the current scenario. Each added tube well was configured to irrigate 0.2 ha of paddy-vegetable, 0.2 ha of vegetable-vegetablevegetable and $0.4-0.5$ ha of cotton-vegetable rotation.

\subsection{Groundwater management and economics}

Supply augmentation is the most common strategy to cope with declining supplies in the low storage rock aquifers however, frequent well drying and reduced water availability in parts of Telangana and Andhra Pradesh has motivated the farmers to selfregulate the groundwater demand (Shah, 2012). Three supply and demand management strategies were evaluated in MIKE SHE/MIKE 11: increased surface water storage, reduced power subsidy and converting flood to drip irrigation (Fig. 2). Switching to less water demanding crops (e.g., rice to pulses) was not considered because most farmers in the watershed are subsistence farmers who grow paddy for their own consumption. Furthermore, in the absence of government support prices for alternative low water demanding crops, farmers are unlikely to stop growing rice which is currently supported by the government.

Water storage structures e.g. check dams and percolation tanks (small ponds) hold the runoff water from a rain event and increase the local groundwater recharge. Increased runoff storage in MIKE SHE/MIKE 11 was implemented by increasing the detention stor- age and doubling the design storage capacity of the existing seven in-stream check dams (Fig. 1). In MIKE SHE/MIKE 11, increasing the detention storage is equivalent to trapping runoff in distributed percolation tanks or depressions. Detention storage was increased by $1 \mathrm{~mm}$ to increase the storage capacity by $3000 \mathrm{~m}^{3}$; this is equivalent to adding 80 typical percolation tanks ( $6 \mathrm{mx} 6 \mathrm{mx} 1 \mathrm{~m})$ in the watershed. Doubling of check dam storage capacity was achieved by increasing the existing dam elevation where the topography permitted i.e. the crest elevation of the modified dam was kept at least $0.5 \mathrm{~m}$ below the ground level to avoid flooding. At places, where topography didn't permit the doubling of damming height, the bottom of the stream was lowered to achieve the doubling of check dam height. Lower stream bottom is achieved by dredging the stream bottom to remove the sediment accumulated over the years; reservoir sedimentation is a global problem which causes loss of storage and reservoir functions (Kondolf et al., 2014). Doubling the height of check dams in the watershed almost doubled their storage capacity to $12,600 \mathrm{~m}^{3}$ ( $4 \mathrm{~mm}$ ).

A $50 \%$ reduction in power subsidy ( $3.5 \mathrm{~h}$ compared to seven hours of daily free electricity) was simulated by reducing the daily maximum irrigation pumpage by 50\% in the MIKE SHE/MIKE 11. Measured pump flow rates and seasonal water application suggest that daily $3.5 \mathrm{~h}$ of free electricity/pumping is sufficient to meet the current crop water demands. Drip irrigation in MIKE SHE was simulated by triggering the irrigation based on the ET deficit and filling the soil to field capacity (instead of saturation under the flood method); irrigation was triggered when actual ET dropped below $90 \%$ of reference ET. Under flood method, the irrigation was triggered when available soil moisture (difference between actual moisture and wilting point) reached at $40 \%$ and $50 \%$ of maximum available moisture (saturation minus wilting point) during Kharif and Rabi season, respectively.

Well drying will limit the irrigation water availability and adversely affect the crop yield, especially during the dry season. Yield effects of demand and supply management options (Fig. 2) were analyzed using the duration of no water (well drying) in the tube wells in the watershed. Partial crop damage is assumed to occur when a well is dry during final 20-40 days of the growing season. Although the crop may die under such moisture stress, farmers are likely to get 1-2 harvesting of vegetables (tomato or pepper). Major crop damage is assumed to occur when the well is dry 
during the last 40 or more days before end of the growing season (100-120 days). A conservative estimate of 30\% and 70\% yield loss was taken under partial and major crop damage, respectively. Average conversion rate of 1 US $\$=54$ Indian Rupee during 2012-2013 was used to assess the economic impacts. Cropped area affected, yield and income under no management change (i.e. no intervention) were compared with those under different demand and supply management options under high well growth scenario.

Reduced water application under drip irrigation is likely to result in energy savings as compared to the conventional flood irrigation. Energy consumptions under no intervention (i.e. entire flood irrigation) and 50\% drip adoption were estimated for state of Andhra Pradesh under low withdrawal scenario (2035) (Fig 2). State of Andhra Pradesh here refers to former (prior to June 2014) undivided state of Andhra Pradesh which include present states of Telangana and Andhra Pradesh. The well growth rate under low scenario is representative of the historical (1994-2007) growth rate in Andhra Pradesh ( 23 wells $/ 100 \mathrm{~km}^{2} /$ year). There were 1.2 million shallow and deep tube wells in the Andhra Pradesh during 20062007 (DES, 2013a) and the assumed irrigation well growth rate of 23 wells $/ 100 \mathrm{~km}^{2} /$ year would result in 2.96 million tube wells by 2035. Energy consumption in pumping was calculated from the following equation (Qureshi, 2014):

$$
\text { Energy consumed }(\mathrm{kwh})=\frac{2.73 \times \mathrm{Q} \times \mathrm{H}}{\mathrm{PSE} \times(1-\mathrm{TDL}) \times 1000}
$$

where,

$$
\begin{aligned}
& \mathrm{Q}=\text { pump flow volume }\left(\mathrm{m}^{3}\right) \\
& \mathrm{H}=\text { total head - dynamic and pressure }(\mathrm{m}) \\
& \mathrm{PSE}=\text { pump system efficiency (fraction) } \\
& \mathrm{TDL}=\text { electricity transmission and distribution losses (fraction) }
\end{aligned}
$$

Annual water application per tube well under flood system was estimated from measured duration and rates of pumping in the watershed. Average reduction in water application (30\%) due to drip adoption, compared to the flood method in India, was taken from literature (Narayanamoorthy, 2004). Total head under flood and drip irrigation were taken as $65 \mathrm{~m}$ and $48 \mathrm{~m}$, respectively; these heads were estimated from observed drawdown during pumping and MIKE SHE simulated average groundwater levels under low scenario with no intervention and 50\% drip irrigation. To maintain adequate pressure in drip lines, $5 \mathrm{~m}$ of pressure head was accounted into total head calculations under drip system. The PSE and TDL values were taken as 40\% (Qureshi, 2014) and 35\% (Dubash, 2007), respectively, resulting in overall system efficiency (PSE* $(1-\mathrm{TDL}))$ of $26 \%$ which is comparable to the values used in literature (Shah et al., 2004). Monetary value of energy consumptions were estimated from unit cost of power supply $(\$ 0.097 / \mathrm{kwh})$ during 2012-2013 (GOI, 2014).

\section{Results and discussion}

\subsection{Model evaluation}

Calibration and validation results showed that the model captured the variation in both groundwater and surface water levels (Fig. 3a-c). Model performance varied from "good" to "very good" depending on the calibration and validation target (surface or ground water levels) and location (Table 2). The RMSE values for the groundwater head simulations ranged from 0.62 to $2.7 \mathrm{~m}$, which is $21-57 \%$ of the standard deviation in the observed data. Among the monitored tube wells, the best NSE (0.95) and RMSE $(0.75 \mathrm{~m})$ for abandoned well (T-4), confirmed the model's ability to simulate the natural background groundwater levels in the watershed. Rapid recession and recovery of groundwater head during and after pumping introduces large fluctuations in the groundwater levels in the tube wells. The model performance in simulating the surface flow and levels was considered as "very good" (Table 2, Fig. 3c). Negative PBIAS value indicates that the model tends to over-predict the surface flow, especially for high rainfall events (Fig. 3d). During September-December period, over-prediction of groundwater levels resulted in higher streamflow and surface water level predictions.

\subsection{Water balance}

\subsubsection{Current withdrawals}

Water balance for the 14-year period (2000-2014) (Table 3) showed that ET is by far the largest outflow component accounting for $84 \%$ of the annual rainfall (average rainfall $=838 \mathrm{~mm}$ ). Average annual surface outflow was $17 \%$ of the rainfall and most (89\%) of it occurred during the monsoon season (June-October); $85 \%$ of rainfall was received during the monsoon. The stream in the watershed is a losing stream (recharges aquifer) during the initial part of monsoon (June-August) however, it becomes a gaining stream (receives groundwater flow) later (September-November). Annual streamflow varied based on the rainfall received and increased dramatically during above average rainfall years such as 20052006 (194 mm), 2008-2009 (582 mm) and 2010-2011 (264 mm) (Table 3).

Groundwater recharge is derived from rainfall, seepage from water harvesting structures (e.g. check dams - Fig. 1) and irrigation return flows. Net groundwater recharge varied with annual rainfall and groundwater withdrawals. An above average rainfall year such as 2005-2006, resulted in positive net groundwater recharge $(42 \mathrm{~mm})$ while a below average rainfall year such as 2002-2003 resulted in negative net recharge $(-103 \mathrm{~mm})$ (Table 3$)$. High irrigation demand during below average rainfall year further causes groundwater declines and stresses the irrigation supply and environmental surface flows; during 2002-2003, which was a drought year (rainfall $=559 \mathrm{~mm})$, the surface flows were negligible $(2 \mathrm{~mm})$ from the watershed. Extreme hydrologic conditions e.g. drought (2002-2003) or floods (e.g. 2008-2009) are likely to negatively affect the farmers by inflicting crop and property damage. For example, massive flood in Krishna river during 2009 claimed more than 300 lives, destroyed vast areas of crops and flattened more than a million houses in the states of Karnataka and Andhra Pradesh (Sphere India, 2009; Killada et al., 2012).

\subsubsection{Future withdrawals}

Net groundwater recharge decreased under all future groundwater withdrawal scenarios (low, medium and high) compared to the current scenario (Table 4). This decrease, despite increased recharge $(10-17 \mathrm{~mm})$ due to higher infiltration of rainfall and irrigation, was due to increased pumping (25-51 mm) and ET (20$45 \mathrm{~mm}$ ) from additional irrigated areas in the future. All the crops in the watershed are flood irrigated where non-productive evaporation losses are higher compared to more efficient methods such as drip irrigation. Expanded irrigated area increased the fraction of rainfall transferred into pumping and ET from 19\% and $84 \%$ under current withdrawals to $25 \%$ and $89 \%$ under high withdrawals, respectively. Almost entire increase in pumping $(51 \mathrm{~mm})$ is transformed into ET $(45 \mathrm{~mm})$ under the high withdrawal scenario.

Increased withdrawals also reduced the average annual streamflow by $13-26 \%$ (Table 4). Number of streamflow days in a year reduced by little over a month (96 days-64 days) under the high withdrawal scenario compared to current scenario. Lowered water table, a result of increased groundwater abstraction, reduced baseflow volume and duration under all three future withdrawal scenarios (Table 4). Baseflow is an important part of streamflow especially during below average rainfall years and its reduction along 

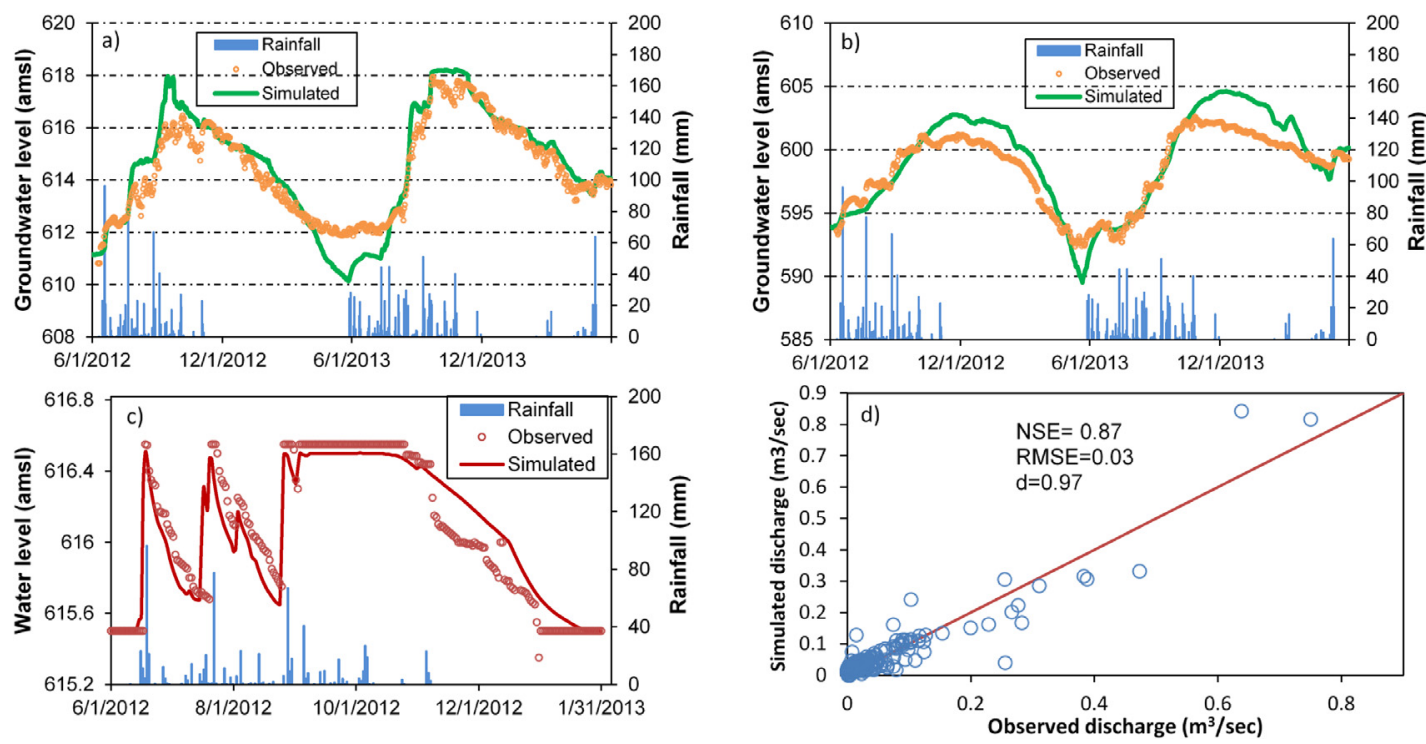

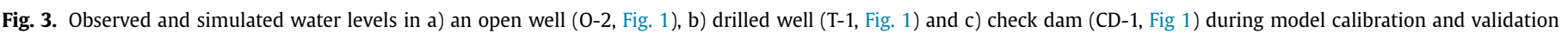

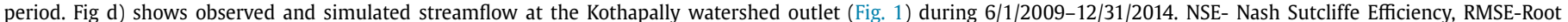
Mean Square Error and d-Willmott's Index of Agreement.

Table 2

Model performance statistics for surface and groundwater level predictions during the calibration (6/2012-5/2013) and validation (6/2009-5/2014) periods. Root Mean Square Error (RMSE) is expressed in $m$ and Percent bias (PBIAS) as \%.

\begin{tabular}{lllllll}
\hline Period & Target & Location ID $^{\mathrm{a}}$ & NSE $^{\mathrm{b}}$ & RMSE $^{\mathrm{c}}$ & $\mathrm{D}^{\mathrm{d}}$ & PBIAS $^{\mathrm{e}}$ \\
\hline Calibration & Groundwater levels (2012-2013) & $\mathrm{O}-1$ & 0.67 & 0.86 & 0.94 & -0.03 \\
& & $\mathrm{O}-2$ & 0.78 & 0.95 & 0.95 & $-8 \times 10^{-3}$ \\
& & $\mathrm{~T}-1$ & 0.79 & 1.89 & 0.94 & -0.10 \\
& & $\mathrm{~T}-2$ & 0.70 & 1.48 & 0.94 & -0.08 \\
& & $\mathrm{~T}-3$ & 0.67 & 2.7 & 0.91 & -0.30 \\
Validation & Surface water levels (2012-2013) & $\mathrm{CD}-1$ & 0.76 & 0.16 & 0.94 & $-1.3 \times 10^{-3}$ \\
& Groundwater levels (2013-2014) & $\mathrm{O}-1$ & 0.89 & 0.62 & 0.98 & -0.02 \\
& & $\mathrm{O}-2$ & 0.87 & 0.72 & 0.97 & $-8.6 \times 10^{-3}$ \\
& & $\mathrm{~T}-1$ & 0.94 & 1.24 & 0.98 & -0.15 \\
& & $\mathrm{~T}-2$ & 0.73 & 1.52 & 0.95 & -0.10 \\
& & $\mathrm{~T}-3$ & 0.91 & 1.60 & 0.97 & $-2.3 \times 10^{-5}$ \\
& & $\mathrm{~T}-4$ & 0.95 & 0.75 & 0.99 & -0.05 \\
\hline
\end{tabular}

a See Fig. 1.

b Nash Sutcliffe Efficiency.

c Root Mean Square Error.

d Willmott's Index of Agreement.

e Percent Bias.

Table 3

Water balance components (mm) for Kothapally watershed under current withdrawals scenario. The values are for a hydrological year (June 1-May 31). Current withdrawal scenario represents present (2015) pumping rates in the watershed.

\begin{tabular}{llllllll}
\hline Year & Rainfall & ET & Streamflow $^{\mathrm{a}}$ & Recharge $^{\mathrm{b}}$ & Pumping & Baseflow $^{\mathrm{c}}$ Net recharge $^{\mathrm{d}}$ \\
\hline $2000-2001$ & 973 & 706 & 394 & 310 & 171 & 151 & -12 \\
$2001-2002$ & 747 & 705 & 50 & 179 & 176 & 11 & -8 \\
$2002-2003$ & 559 & 699 & 2 & 68 & 175 & -5 & -103 \\
$2003-2004$ & 843 & 688 & 24 & 188 & 153 & -8 & 43 \\
$2004-2005$ & 747 & 725 & 38 & 248 & 162 & 13 & 73 \\
$2005-2006$ & 1076 & 742 & 194 & 300 & 134 & 124 & 42 \\
$2006-2007$ & 484 & 641 & 54 & 137 & 175 & 30 & -67 \\
$2007-2008$ & 1090 & 754 & 152 & 299 & 131 & 97 & 71 \\
$2008-2009$ & 1123 & 703 & 582 & 398 & 165 & 269 & -36 \\
$2009-2010$ & 721 & 689 & 52 & 144 & 171 & 2 & -30 \\
$2010-2011$ & 980 & 697 & 264 & 367 & 153 & 176 & 37 \\
$2011-2012$ & 720 & 688 & 89 & 201 & 175 & 54 & -29 \\
$2012-2013$ & 742 & 694 & 40 & 165 & 178 & 3 & -17 \\
$2013-2014$ & 928 & 734 & 83 & 258 & 133 & 60 & 65 \\
Average & 838 & 704 & 144 & 233 & 161 & 70 & 2
\end{tabular}

a Streamflow includes the overland flow and baseflow.

b Recharge is the total amount of water reaching the water table and does not include the losses due to baseflow.

c Negative baseflow indicates net inflow into aquifer due to stream recharge.

d Net recharge is the net change in the aquifer storage and includes the recharge, pumping, baseflow and ET fluxes. 
Table 4

Average annual (6/1/2000-5/31/2014) water balance components ( $\mathrm{mm}$ ) under current and future groundwater withdrawal scenarios. Values in the parenthesis show the changes in components as compared to the current withdrawals scenario. The current withdrawal scenario represents present (2015) pumping rates and low, medium and high scenario represents future (2035) pumping rates under low (20 wells $/ 100 \mathrm{~km}^{2} /$ year), medium ( 30 wells $/ 100 \mathrm{~km} /$ year) and high (50 wells $/ 100 \mathrm{~km}^{2} /$ year) growth of irrigation wells.

\begin{tabular}{lllllll}
\hline Scenario & Pumping & Recharge $^{\mathrm{a}}$ & Baseflow & Net recharge $^{\mathrm{b}}$ & ET & Streamflow $^{\mathrm{c}}$ \\
\hline Current & 161 & 233 & 70 & 2.12 & 704 & 144 \\
Low & $186(+25)$ & $243(+10)$ & $55(-14)$ & $1.67(-0.45)$ & $724(+20)$ & $126(-18)$ \\
Medium & $198(+37)$ & $247(+14)$ & $49(-20)$ & $-0.23(-2.35)$ & $735(+30)$ & $118(-26)$ \\
High & $212(+51)$ & $250(+17)$ & $42(-25)$ & $-3.70(-5.82)$ & $749(+45)$ & $107(-37)$ \\
\hline
\end{tabular}

a Recharge is the total amount of water reaching the water table and does not include the losses due to baseflow.

b Net recharge is the net change in the aquifer storage and includes the recharge, pumping, baseflow and ET.

c Streamflow includes the overland flow and baseflow.

with decreased flow duration is likely to worsen surface water availability for not only drinking and power generation but also downstream ecological systems that depend on it.

Osman Sagar and Himayat Sagar reservoirs, built on the Krishna river's tributaries to provide water supply to Hyderabad city (2011 population $=6.8$ million), are already experiencing reduced Inflows (George et al., 2009). Future increases in regional withdrawals are likely to reduce the basin inflows into Krishna River which provides water to four Indian states: Maharashtra, Karnataka, Telangana and Andhra Pradesh (2011 population $=258$ million). Future changes in monsoon variability such as increased frequency of high rainfall events and wet season dry spells and decreased rainy days (Sharmila et al., 2015) may exacerbate both flooding and drought in this semi-arid region. More frequent and intense extreme flood events (e.g., 2009) would aggravate crop and property damages and human suffering. Although increased rainfall may enhance the surface flows and groundwater recharge, increased frequency of high rainfall events combined with decreased number of rainy days, and intensified groundwater withdrawals, may further reduce the water availability unless the wet season flows are captured and used in the dry season. As of March 2016, seasonal basin inflows to the Krishna have reduced by $90 \%$ compared to average historical inflows (http://www.thehindu.com/news/cities/Vijayawada/ inflows-into-krishna-basin-take-a-dip/article8394784.ece) which is partly due to below average monsoon rainfall during 2015. Fourth largest river in India, the Krishna provides water for irrigation, domestic and industrial uses, hydroelectric generation (13 dams including the Srisailam and Nagarjuna Sagar dam with $1670 \mathrm{MW}$ and $815 \mathrm{MW}$ capacities, respectively), and ecosystem in the southern Indian region. Predicted reductions in surface flow volume (13-26\%) and duration (up to 33\%) due to growth of irrigation wells in future will exacerbate both surface-water and groundwater availability in Andhra Pradesh as well other hard rock regions of India (240 million ha).

\subsection{Water availability under future withdrawals}

\subsubsection{Groundwater decline}

Future increase in groundwater withdrawals significantly lowered the groundwater levels and affected water availability. Compared to the current scenario, average annual groundwater levels in a monitored tube well (Fig. 4) declined by 8,15 and $32 \mathrm{~m}$ under low, medium and high withdrawal scenarios, respectively. These declines were much more pronounced during the dry season (November-May) (Fig. 4) when groundwater is most critical for irrigated agriculture. Many of the tube wells in the watershed are $50-70 \mathrm{~m}$ deep (pumps located at $40-50 \mathrm{~m}$ ) and this decline is likely to make them unproductive during a large part of the dry season limiting the ability to grow crops. Larger declines in groundwater levels were predicted during consecutive below average rainfall years such as 2001-2003 (Fig. 4). Under high with- drawal scenario, a $58 \mathrm{~m}$ decline in groundwater levels was predicted during 2002-2003 which was a drought year preceded by a year of below average rainfall (Fig. 4).

Rainfall driven large fluctuations in groundwater levels shows the flashy nature of rock aquifer which is due to low storage capacity of the weathered fractured system. The 2008-2009 period was the highest rainfall year (rainfall $=1123 \mathrm{~mm}$ ) but the net recharge was still negative (Table 3 ) under current withdrawals because the aquifer had limited space to store recharge. The negative net recharge was due to above average rainfall during previous year (2007-2008) and hence almost half of the rainfall in 2008-2009 converted into streamflow. Despite consecutive above average annual rainfall during 2007-2009, groundwater levels declined significantly during the next year (2009-2010) under the high withdrawals scenario (Fig. 4). Low storage capacity of aquifer limits its resilience against drought and below average rainfall and makes the irrigated agriculture highly vulnerable to inherent variability in monsoon rainfall. Although groundwater levels reverted back to normal $(596 \mathrm{~m})$ during consecutive above average rainfall years (e.g. 2007-2009), declines in groundwater levels and resulting well drying in future drought years is likely to cause irreversible damages to agricultural and ecological systems.

\subsubsection{Well drying}

Crop failure associated with well drying is one of the main causes of farmers' distress in this hard rock region of India (Mohanty and Shroff, 2004; Rao and Suri, 2006). Famers' suicides in Andhra Pradesh peaked during 2004-2006 (Gruere et al., 2008; NCRB, 2001-2012) which was followed by a severe drought in 2002-2003 (rainfall $=559 \mathrm{~mm}$ ). These unfortunate events are caused by farmer's inability to repay the loans taken for agricultural expenses including well installation. All the years during 2001-2005 were either average or below average rainfall years (average rainfall $=838 \mathrm{~mm}$ ) which caused the water levels to drop below the well bottom.

Depth of existing wells in the watershed ranges from $50-120 \mathrm{~m}$. Wells approach the critical level during consecutive below average or average rainfall years (Fig. 5). Median number of dry well (groundwater depth> well depth) days during 2002-2003 increased by 34 and 365 days for both low and high withdrawal scenarios, respectively compared to current scenario (Fig. 5). In contrast to current scenario, a below average rainfall year is likely to cause water scarcity during most of the year under high withdrawals scenario. Even during above average rainfall years such as 2005-2006 (rainfall $=1076 \mathrm{~mm}$ ), median number of dry well days increased by 81 days under high withdrawals (Fig. 5). Increased duration and frequency of well drying will directly affect the yield of high-value vegetable crops grown during Rabi and summer seasons.

Under the high withdrawals scenario wells were dry for longer duration with the exceptions of 2007-2009 when consecutive 


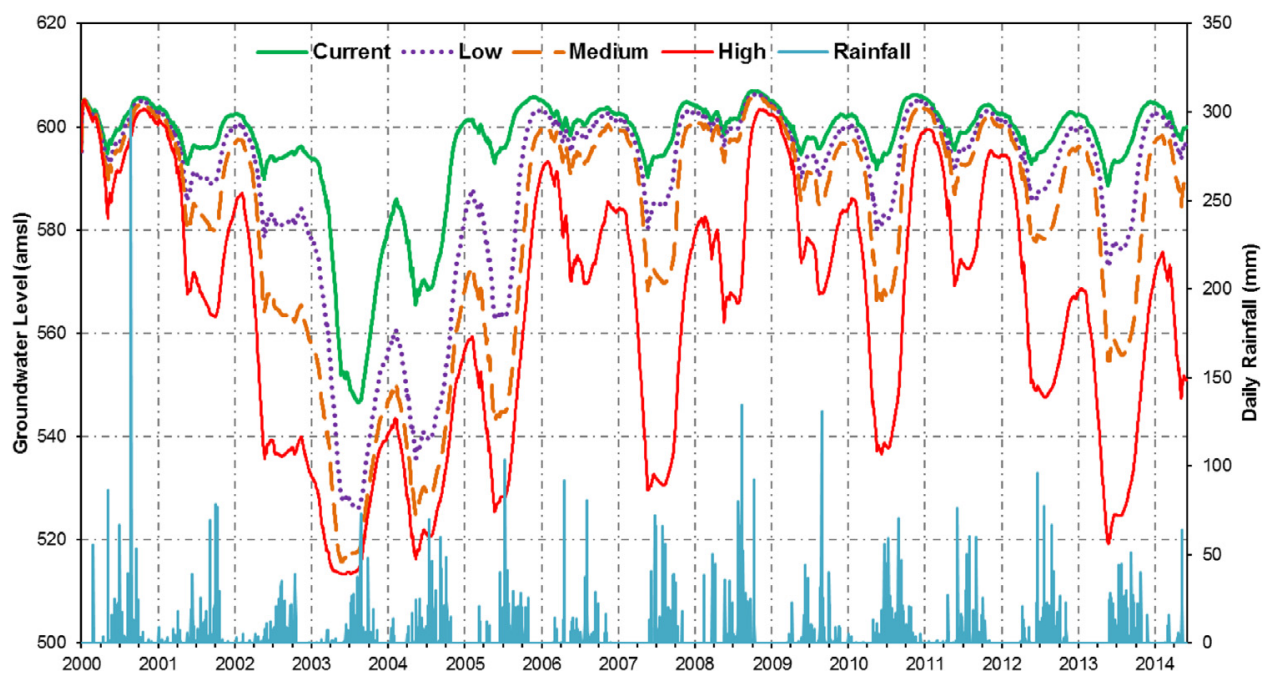

Fig. 4. Groundwater levels in a monitoring tube well (T-2, Fig. 1) under current and future groundwater withdrawal scenarios. Current scenario represent current (2015) pumping rates and low, medium and high scenario represents future (2035) pumping rates under low $\left(20\right.$ wells $\left./ 100 \mathrm{~km}^{2} / \mathrm{year}\right)$, medium $\left(30\right.$ wells $\left./ 100 \mathrm{~km}{ }^{2} / \mathrm{year}\right)$ and high (50 wells $/ 100 \mathrm{~km}^{2} /$ year) irrigation well growth rates.
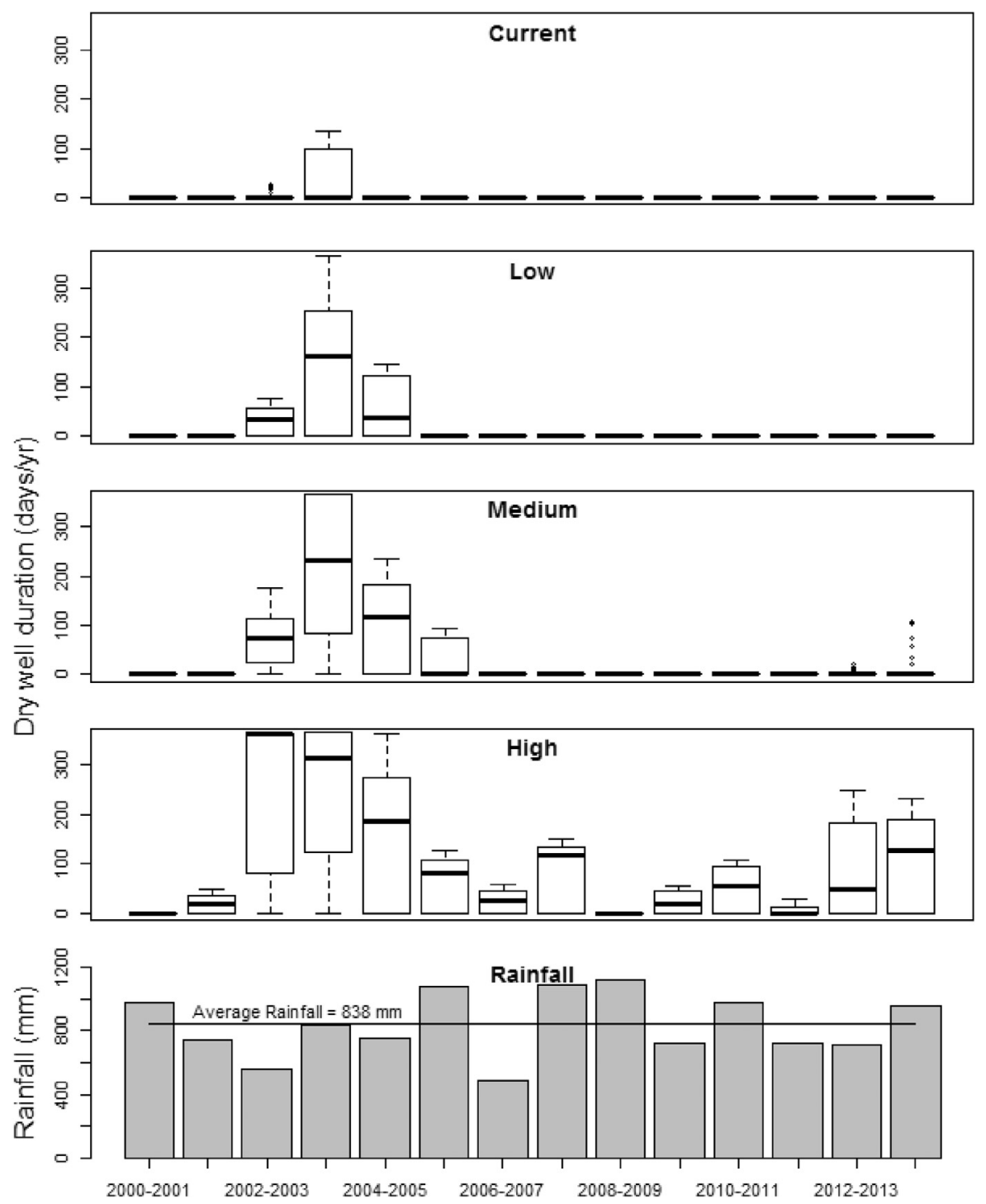

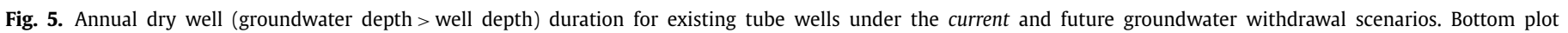

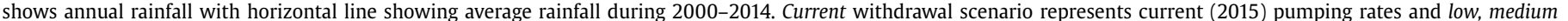

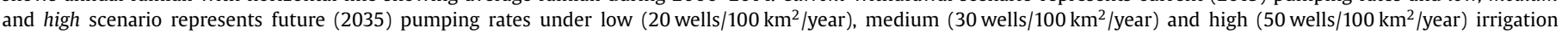
well growth rates. 


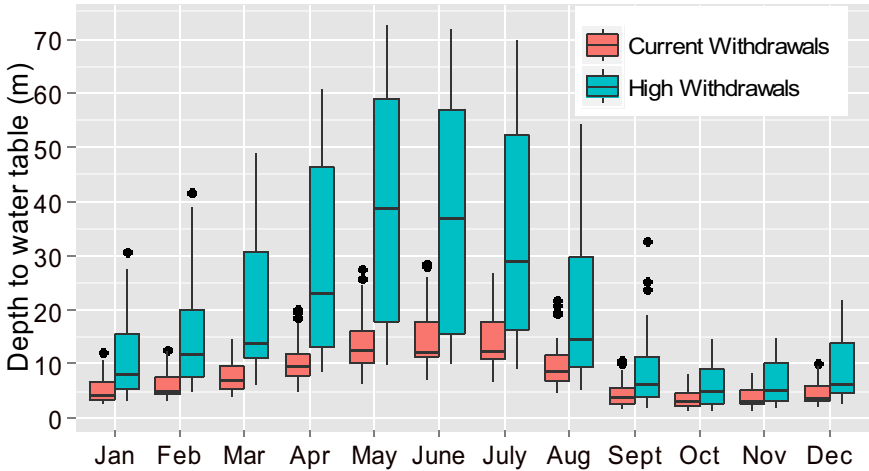

Fig. 6. Tukey's Box plot comparing average monthly water table depths in existing open wells (total 31) under current and high groundwater withdrawal scenarios. The dots above and below the box represent outliers. Current withdrawal scenario represent current (2015) pumping rates and high scenario represents future (2035) pumping rates under high ( 50 wells $/ 100 \mathrm{~km}^{2} /$ year) irrigation well growth rate.

above average rainfall fell in the watershed. Consecutive above average rainfall helps mitigate well drying but consecutive below average rainfall years (2002-2005) dried up most of the wells in the watershed irrespective of the withdrawal scenario considered (Fig. 5). Wells located in upland areas were more prone to drying, compared to the wells located in low lying areas.

The threshold groundwater depth in open wells for it to be dry is approximately $10 \mathrm{~m}$ since most well bottoms in the watershed are at this depth. Compared to the current withdrawals, open wells were predicted to dry earlier in the dry season under all three future withdrawal scenarios. Results for the high scenario showed that the open wells would start drying two month earlier in February compared to April under the current withdrawal scenario (Fig. 6). Earlier drying will be damaging to crops because water supply during January-March is critical for Rabi season crops. Increased withdrawals also prolonged the well drying duration from April-July under the current withdrawals to FebruaryAugust under high withdrawals (Fig. 6). Extension of well drying into the mid-monsoon is not only damaging to agriculture but also surface flows (baseflow and overland flow) which affect the reservoir storage, hydroelectric generation, and downstream ecologies. Half of the wells in the watershed are open wells and such early and prolonged drying would limit the irrigation supply especially for those economically weaker farmers who cannot afford the construction cost of deeper tube wells fitted with electric pumps.

\subsection{Groundwater management}

Given earlier and more frequent well drying predicted for future, integrated water and energy management options to maintain/enhance current groundwater recharge and supply were considered. Two types of water management strategies viz. demand and supply management were considered. Demand management strategies usually include efficient irrigation techniques such as drip irrigation, switch to low water demanding crops and deficit irrigation. Reforms in power subsidy policy were considered to help manage the groundwater demand. On the other hand, supply augmentation strategies in India are usually focused on increasing the groundwater recharge through water storage structures such as check dams, percolation tanks, and farm ponds.

\subsubsection{Supply management: water storage}

Enhanced water storage improved the groundwater levels especially during above average rainfall years followed by a below average rainfall year. For example, even under the high withdrawal scenario, average groundwater levels during 2007-2008 rose by
$29 \mathrm{~m}$ (Fig. 7). Net groundwater recharge increased for multiple years such as 2005-2006 (107 $\mathrm{mm}$ with enhanced storage minus $76 \mathrm{~mm}$ under current condition $=27 \mathrm{~mm})$ and $2009-2010(20 \mathrm{~mm})$ (Table 5). Increased water storage under the high withdrawals scenario enhanced the water availability by reducing the well drying duration especially during the most severe drought of 20022003 (190 days/year) (Fig. 8). However, increased water storage also decreased surface outflows (e.g. $24 \mathrm{~mm}$ or $26 \%$ reduction in 2005-2006) (Table 5) from the watershed which has potential implications (ecological, power generation and water supply) of reduced downstream flows to Krishna river. Similarly, although the net recharge increased (Table 5), it didn't help mitigate the well drying during 2003-2005 (Fig. 8). Increased net recharge helped sustain water availability during the drought of 2002-2003 but most of the wells could not sustain the high water demands during 2003-2005 thereby resulting in no net positive effect on well drying. Compared to a high net negative recharge during extreme drought (2002-2003, -97 mm) (Table 5), enhanced net recharge wasn't sufficient to replenish the aquifer storage and mitigate the well drying for the next two years (2003-2005). Absence of above average rainfall and surface flows to store, increased storage measures didn't help improve the groundwater availability during 2003-2005. Overall, although the water storage does improve the groundwater availability for above and below average rainfall year including drought, it does not mitigate low water availability during consecutive average or below average rainfall years. Enhanced water storage may result in small reductions ( $9 \%$, Table 5 ) in surface flows, a tradeoff may have to be considered while designing basin-specific storage structures.

\subsubsection{Demand management}

3.4.2.1. Power subsidy reforms. Power subsidies promote greater agricultural productivity but it does so at the expense of falling groundwater levels (Famiglietti, 2014; Shah et al., 2008). The Telangana state (former Andhra Pradesh state) began providing seven hours of free daily electricity to farmers in 2004 to fulfill the electoral promise of ruling political dispensation. Although the dedicated electric lines were built, they did not provide more than seven hours of electricity, even if a farmer is willing to pay for it. Currently, the electric supply hours are irregular and often occur during night; farmers use automatic switches to turn on the pump whenever the electricity is on. Such night-time pumping results in over-irrigation and wastage of water and energy. A revised power policy providing shorter duration but reliable free electricity hours may help reduce the withdrawals as well as carbon foot-print of irrigation. A $50 \%$ reduction in power subsidy ( $3.5 \mathrm{~h}$ compared to seven hours of daily free electricity) was predicted to raise the groundwater levels significantly during the dry season of many below average rainfall years such as 2006-2007 when levels in May 2007 rose by $26 \mathrm{~m}$ (Fig. 7). Reduced subsidy under the high withdrawals scenario effectively mitigated the well drying during the most severe drought of 2002-2003 (Fig 7). However, similar to the water storage intervention, groundwater levels didn't show significant improvements during the next two years 2003-2005 (Fig. 7). Although the pumping from individual wells reduced due to lower number of free electric hours, the increased number of irrigation wells still caused higher aggregated annual withdrawals $(174 \mathrm{~mm})$ for the high scenario than the current scenario $(157 \mathrm{~mm})$ during 2003-2005 (Tables 3 and 5). Increased groundwater withdrawals offset the water savings achieved through electricity subsidy reduction. It shows that the reduced subsidy doesn't help mitigate the well drying during consecutive below average rainfall periods (Fig. 8). However, money saved through reduced subsidy can be used to fund combination of other management options such as drip and water storage to help increase the water availability during consecutive below average rainfall years. 


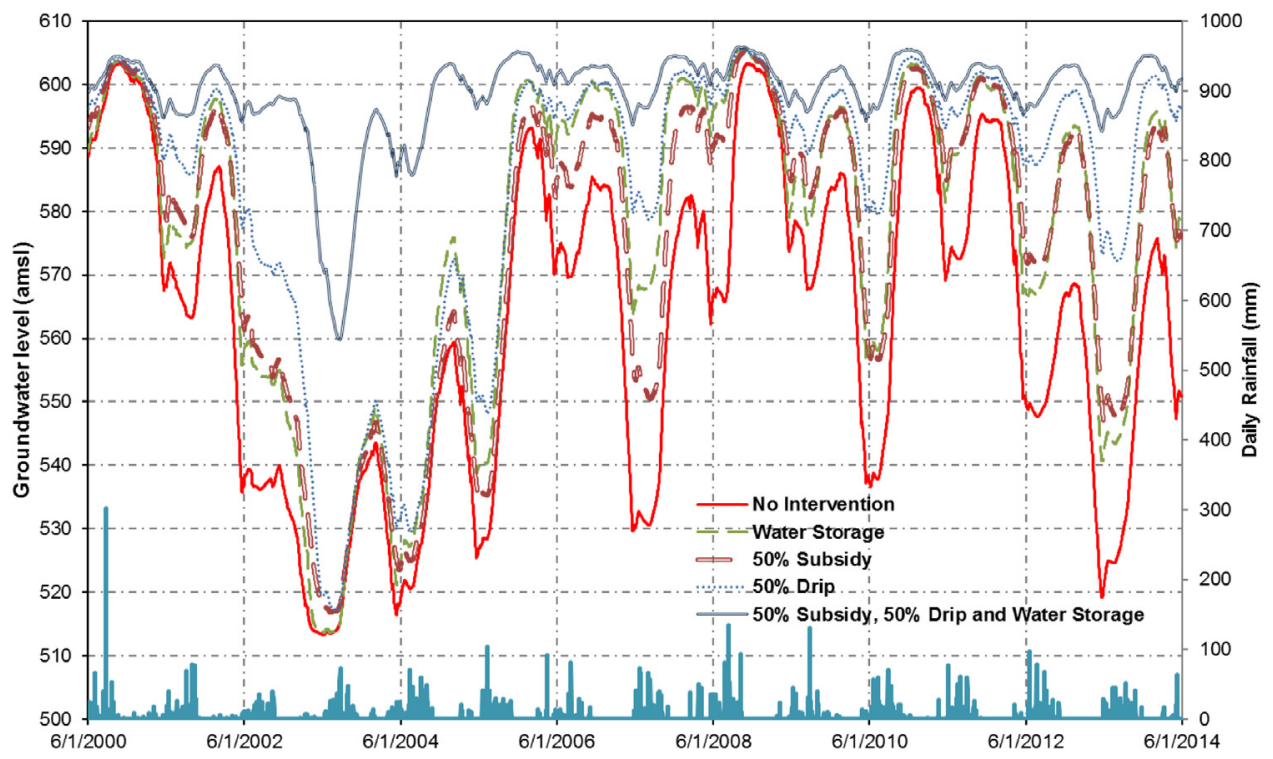

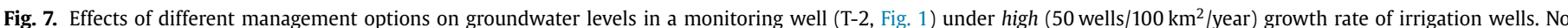

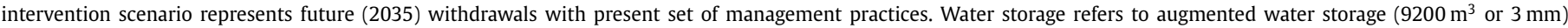

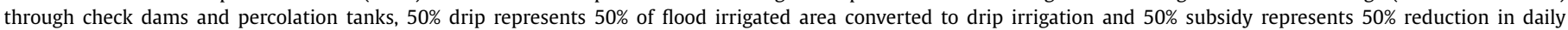
free electricity hours ( $3.5 \mathrm{~h}$ instead of seven).

Table 5

Pumping (P), net recharge (NR) and streamflow (SF) (in $\mathrm{mm}$ ) for different management strategies under high well growth ( 50 wells $/ 100 \mathrm{~km}^{2} /$ year) scenario (2015-2035). No intervention represents current management practice with flood irrigation, water storage refers to augmented water storage $\left(9200 \mathrm{~m}^{3}\right.$ or $3 \mathrm{~mm}$ ) through check dams and percolation tanks, $50 \%$ drip indicates $50 \%$ of flood irrigated area converted to drip irrigation, $50 \%$ subsidy represents $50 \%$ reduction in daily free electricity hours ( $3.5 \mathrm{~h}$ instead of seven).

\begin{tabular}{|c|c|c|c|c|c|c|c|c|c|c|c|c|c|c|c|}
\hline Year & \multicolumn{3}{|c|}{ No intervention } & \multicolumn{3}{|c|}{ Water storage } & \multicolumn{3}{|c|}{ 50\% Subsidy } & \multicolumn{3}{|c|}{$50 \%$ Drip } & \multicolumn{3}{|c|}{ Combined managemen } \\
\hline $2000-2001$ & 244 & -32 & 340 & 241 & -20 & 318 & 226 & -25 & 351 & 204 & -16 & 358 & 180 & -4 & 358 \\
\hline $2002-2003$ & 149 & -63 & -4 & 186 & -97 & -1 & 187 & -92 & -4 & 204 & -119 & 1 & 198 & -96 & -8 \\
\hline 2003-2004 & 159 & 26 & 20 & 169 & 37 & 2 & 155 & 25 & 25 & 150 & 34 & 23 & 169 & 51 & 12 \\
\hline 2004-2005 & 201 & 23 & 31 & 213 & 33 & 13 & 192 & 28 & 38 & 183 & 40 & 34 & 172 & 54 & 36 \\
\hline $2007-2008$ & 182 & 80 & 106 & 186 & 94 & 87 & 178 & 86 & 107 & 162 & 84 & 116 & 146 & 61 & 151 \\
\hline 2008-2009 & 236 & 12 & 476 & 231 & -48 & 524 & 218 & -6 & 507 & 198 & -34 & 547 & 177 & -33 & 556 \\
\hline 2009-2010 & 237 & -79 & 46 & 241 & -59 & 26 & 227 & -70 & 46 & 208 & -50 & 44 & 183 & -26 & 41 \\
\hline $2010-2011$ & 216 & 70 & 190 & 215 & 67 & 185 & 207 & 70 & 198 & 183 & 57 & 220 & 164 & 35 & 258 \\
\hline $2011-2012$ & 252 & -46 & 44 & 248 & -45 & 42 & 235 & -35 & 49 & 210 & -33 & 62 & 186 & -26 & 73 \\
\hline
\end{tabular}

${ }^{a}$ Streamflow includes the overland flow and baseflow.

${ }^{\mathrm{b}}$ Negative streamflow indicates net inflow into aquifer due to stream recharge.

${ }^{\mathrm{c}} \mathrm{Net}$ recharge is the net change in the aquifer storage and includes the recharge, pumping, baseflow and ET fluxes.

3.4.2.2. Switching from flood to drip irrigation. The notion of "free water" i.e. well owners have unlimited access to groundwater, along with the free electricity policy encourages inefficient irrigation practices such as flood irrigation. Replacing low efficiency (45$50 \%$, Sivanappan, 1994) flood irrigation with high efficiency $(90 \%$, Sivanappan, 1994) low-volume drip irrigation, could decrease the groundwater withdrawals and help raise groundwater level and improve groundwater availability. Simulation results showed that implementing drip irrigation in $25 \%$ and $50 \%$ of the irrigated area helped mitigate drastic groundwater level declines during below average rainfall years such as 2006-2007 (Fig. 7). Under the high withdrawal scenario, a $60 \mathrm{~m}$ decline in groundwater levels was predicted during May 2007; the implementation of drip irrigation in $50 \%$ of the irrigated areas reversed the decline and raised the groundwater level by $50 \mathrm{~m}$ (Fig. 7). This benefit of drip irrigation can almost undo the drastic decline in groundwater level and yet support the increased irrigated area. Drip adoption in 50\% of irrigated areas under the high withdrawals helped completely mitigate the well drying during the drought of 2002-2003. Drip conversion also reduced the well drying duration during following below average rainfall period of 2003-2005 although it didn't completely mitigate the drying (Fig. 8). Lower than expected benefit of drip irrigation is due to the use of all water savings achieved through drip conversion to support expanded irrigated areas under the high withdrawal scenario which is also evident from high irrigation withdrawals $(199 \mathrm{~mm})$ and negative net recharge $(-119 \mathrm{~mm})$ during 2002-2003 (Table 5). Water demand of the expanded irrigation area was higher than the available water in wells during 2003-2005, hence flood to drip conversion didn't result in proportionally decreased pumping and increased net recharge. In essence, 


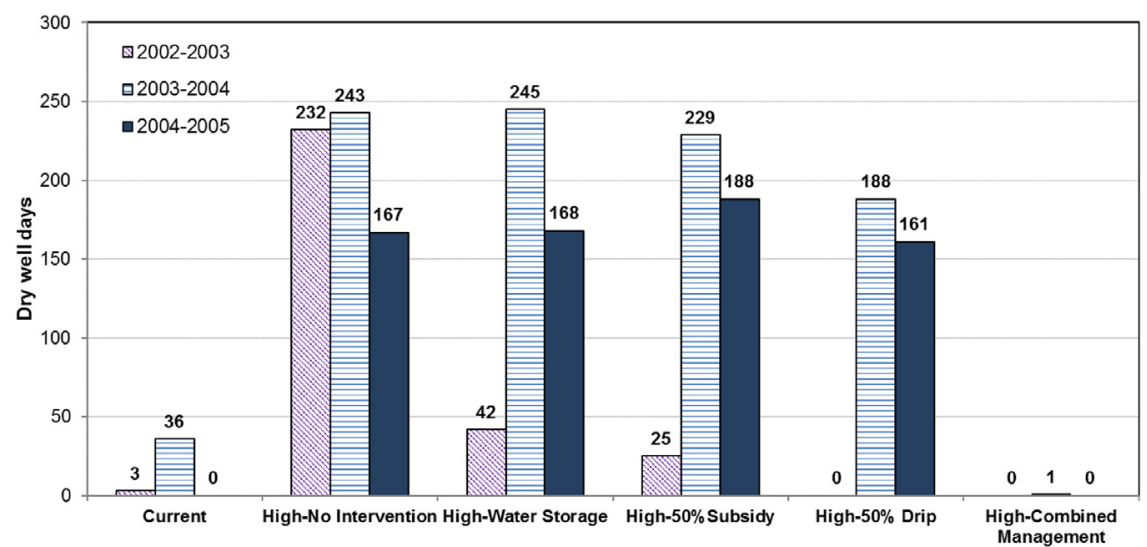

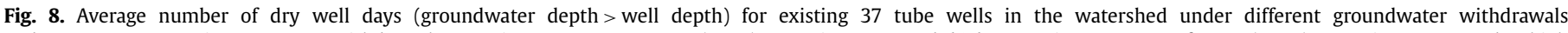

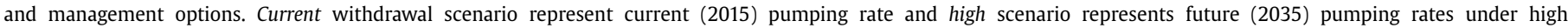

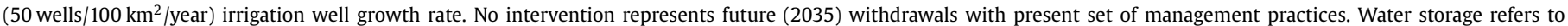

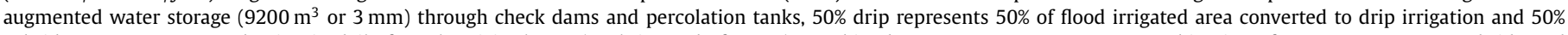

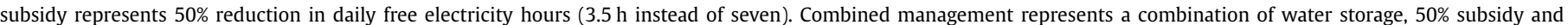
$50 \%$ drip.

although drip conversion alone may support expansion of irrigated areas, it didn't help mitigate the well drying during average and below average rainfall years followed by drought.

\subsubsection{Combined groundwater management strategies}

Model results showed that although an individual management strategy can help raise the groundwater levels during an above and below average rainfall year including drought, it does not solve the well drying problem during average and below average rainfall years (2003-2005) followed by a drought (2002-2003) (Fig. 8). Increased well drying during such periods is likely to cause crop failure leading to farmers' distress. Farmer's distress was one of the main reasons behind the offer of free electricity promise (Dubash, 2007) made by a leading political party in 2004 state elections to increase the water availability.

Combinations of demand and supply management strategies such as reduction in power subsidy, drip conversion and increased watershed storage were also evaluated. The results showed that well drying can be mitigated by implementing more than one management strategies to cope up with the expanded groundwater irrigated areas in future under the high scenario. A combination of these management strategies was effective in completely mitigating the well drying during drought years as well as following average and below average rainfall years such as 2002-2005 (Fig. 8). Prevention of well drying during drought and below average rainfall years such as 2002-2003 (Table 5) indicate sufficient groundwater availability to meet the water demands under the combined management option. On the other hand, compared to the combined and other individual management options, lower withdrawals (Table 5) and increased well drying (Fig 7) during 2002-2003 under no intervention indicates that these low storage aquifers cannot support increased water demands in the future unless water conservation measures are taken. Positive net recharge during 2002-2005 (Table 5) due to enhanced water storage and water use efficiency made sufficient water available for agriculture during the entire period. High negative recharge during 2002-2003 was balanced by enhanced positive net recharge during following years (Table 5). Higher groundwater levels (Fig. 7) also resulted in increased baseflow and streamflow (23\%) under the combined management as compared to the no intervention under high withdrawals (Table 5). In addition to support increased irrigated areas in future, a combined management strategy can enhance surfacewater as well as groundwater levels and flows.

\subsection{Economics of water management options}

Generally, farmers' adoption of a new management technique such as drip irrigation depends on mainly farm profits, market access and technology dissemination policy (Shiferaw et al., 2009). Significant increase in farm revenue or crop yield is a strong incentive to convince the farmers to adopt a management strategy. Almost entire summer crop and more than $60 \%$ of Rabi season crop suffered partial or major damage during an extreme drought (2002-2003) under the high withdrawal scenario without any interventions (Table 6). On an average (2000-2014), about $40 \%$ and $20 \%$ of the irrigated crops suffered partial or major damage during summer and Rabi seasons, respectively (Table 6). Crop damages from almost one-third of the irrigated area would result in farmers' income loss unless the status quo in water management is changed.

Yield and economic benefits under different management strategies were evaluated for cotton (Kharif) and tomato (Rabi and summer season) the two commonly grown crops in the watershed and state. Average reported yield of cotton and tomato during 2012-2013 was 1.2 ton/ha and 14 ton/ha (DES, 2013b), respectively. The market price (US\$) for cotton and tomato during 20122013, $\$ 660$ and $\$ 160 /$ ton, respectively, were used for assessing economic impacts (DES, 2013b). Depending on the management practice implemented, the average additional revenue ranged from $\$ 190$ to $\$ 373$ per farmer who owned deep wells (Fig. 9). The additional income was four to five times higher (\$987-\$1397) during the drought year (2002-2003) compared to the average (20002014). This additional income is significant considering the average annual household income (including the livestock and non-farm sources) of $\$ 1520$ (with $7.74 \%$ of average annual inflation during 2003-2012) in the watershed (Sreedevi et al., 2004). All the demand and supply management strategies considered showed significant benefit during below average rainfall to drought years (e.g. 2002-2003 and 2006-2007; Fig 9). General scarcity of agriculture produce is likely to increase the market prices and net returns during a drought year when crops are most vulnerable to failure. The additional income for Kothapally watershed and other similar areas that are located near large cities (Hyderabad) is likely to be higher than estimated above due to both higher prices, easier access to market, and lower transportation costs.

A preliminary scale-up of economic analysis was conducted to evaluate the cost of the combined management strategy $(50 \%$ 
Table 6

Irrigated area (ha) affected by drying of existing 37 tube wells under the high withdrawal scenario with different management options. None of the tube wells dried up under combined (water storage, $50 \%$ subsidy and $50 \%$ drip) management. Area irrigated under tube wells during Kharif (June-October), Rabi (November-February) and summer (March-May) seasons is 34,34 and 10 ha, respectively.

\begin{tabular}{|c|c|c|c|c|c|c|c|c|}
\hline \multirow[t]{2}{*}{ Year } & \multicolumn{2}{|c|}{ No intervention } & \multicolumn{2}{|c|}{ Water storage ${ }^{a}$} & \multicolumn{2}{|c|}{$50 \%$ Subsidy $^{\mathrm{b}}$} & \multicolumn{2}{|c|}{$50 \%$ Drip $^{c}$} \\
\hline & Rabi & Summer & Rabi & Summer & Rabi & Summer & Rabi & Summer \\
\hline 2000-2001 & 0 & 0 & 0 & 0 & 0 & 0 & 0 & 0 \\
\hline 2001-2002 & 5.5 & 5.1 & 0 & 0 & 0 & 0 & 0 & 0 \\
\hline 2002-2003 & 23.2 & 9.6 & 7.1 & 3.6 & 4.7 & 2.7 & 0 & 0 \\
\hline 2003-2004 & 17.8 & 8.7 & 17.3 & 7.2 & 17.8 & 7.2 & 17.3 & 7.2 \\
\hline 2004-2005 & 11.1 & 7.2 & 10.7 & 3.6 & 14.7 & 5.4 & 12.4 & 4.2 \\
\hline $2005-2006$ & 0 & 0 & 0 & 0 & 2.4 & 0 & 0 & 0 \\
\hline 2006-2007 & 7.5 & 6.3 & 0 & 0 & 0 & 0 & 0 & 0 \\
\hline 2007-2008 & 0 & 0 & 0 & 0 & 3 & 0 & 0 & 0 \\
\hline 2008-2009 & 0 & 0 & 0 & 0 & 0 & 0 & 0 & 0 \\
\hline 2009-2010 & 7.5 & 5.4 & 0 & 0 & 0 & 0 & 0 & 0 \\
\hline 2010-2011 & 0 & 0 & 0 & 0 & 0 & 0 & 0 & 0 \\
\hline 2011-2012 & 0 & 1.2 & 0 & 0 & 0 & 0 & 0 & 0 \\
\hline 2012-2013 & 12 & 8.1 & 0 & 0 & 0 & 0 & 0 & 0 \\
\hline 2013-2014 & 5 & 3.3 & 4.2 & 0 & 3.3 & 0 & 0 & 0 \\
\hline Average & 6.4 & 3.9 & 2.8 & 1 & 3.2 & 1 & 2.1 & 0.8 \\
\hline
\end{tabular}

a Water storage refers to augmented water storage $\left(9200 \mathrm{~m}^{3}\right.$ or $3 \mathrm{~mm}$ ) through check dams and percolation tanks.

b $50 \%$ subsidy represents $50 \%$ reduction in daily free electricity hours ( $3.5 \mathrm{~h}$ instead of seven).

c $50 \%$ drip indicates $50 \%$ of flood irrigated area converted to drip irrigation.

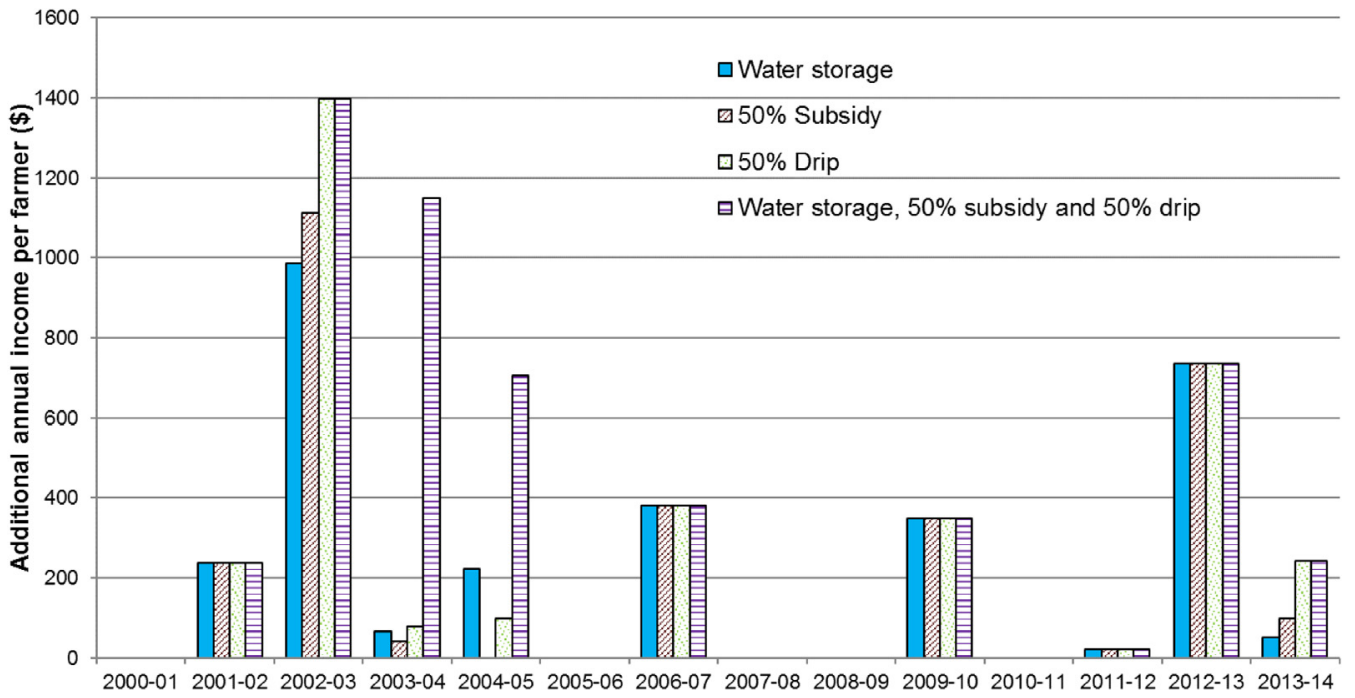

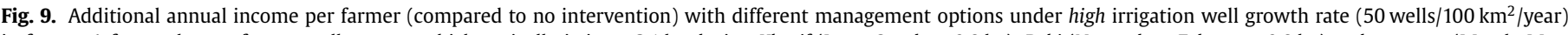

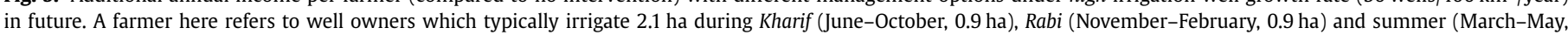

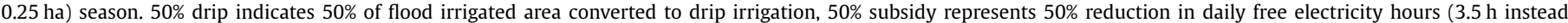
of seven) and water storage refers to augmented water storage ( $9200 \mathrm{~m}^{3}$ or $3 \mathrm{~mm}$ ) through check dams and percolation tanks.

drip, half subsidy and increased water storage) at the state level (Andhra Pradesh, area $=27.5$ million ha). For scale-up, it was assumed that land use and geophysical environment of rest of the state are similar to the Kothapally watershed. Based on the average cost of check dams $\left(\$ 2.9 / \mathrm{m}^{3}\right)$ and percolation tanks $\left(\$ 0.97 / \mathrm{m}^{3}\right)$ constructed in the Kothapally (Wani et al., 2003) and surrounding region, about $\$ 2.9$ billion (7.74\% of average annual inflation during 2003-2012) would be needed to create additional watershed storage capacity of $5 \mathrm{~mm}\left(1375\right.$ million $\left.\mathrm{m}^{3}\right)$ in the state; $3 \mathrm{~mm}$ $\left(825\right.$ million $^{3}$ ) from check dams and $2 \mathrm{~mm}\left(550\right.$ million $\left.\mathrm{m}^{3}\right)$ from percolation tanks. Considering that past watershed development programs have already installed some of these structures in the state (Massuel et al., 2014), $5 \mathrm{~mm}$ addition in the storage would make the storage capacity of the state similar to the Kothapally watershed under the increased water storage scenario. In 20122013, 2.6 million ha area was irrigated by groundwater in the state of Andhra Pradesh. Assuming similar growth (high) in groundwa- ter irrigated area in the state (50\% in next 20 years), converting $50 \%$ of irrigated area (1.95 million ha) from flood to drip irrigation would cost about $\$ 3.1$ billion ( $\$ 1600 /$ ha; Kakhandaki et al., 2012). Added together, the total cost of drip irrigation and water storage structures would be about $\$ 6$ billion; this is almost one fourth of the state revenue during 2012-2013. Power subsidy to Andhra Pradesh farmers in 2012-2013 was \$2 billion (GOI, 2014). A 50\% reduction in power subsidy would save $\$ 1$ billion every year and six years of subsidy savings could fund drip installation and construction of water storage structures in the state. Under businessas-usual management with high withdrawals, electric energy consumption, and therefore subsidy, for existing tube wells will increase by $108 \%$ due to pumping from deeper depths. Therefore, under the high scenario only three years of subsidy savings can fund $50 \%$ drip conversion and water storage structures in the state. In addition to being economically desirable to the state, a combination of these management strategies will also provide irrigation 
water to expanded irrigated area thereby increasing the agricultural production and improving farmer's livelihood. Although, similarly increased water storage in the entire region would reduce the surface flows thereby impacting the water availability and power generation downstream. A detailed region specific tradeoff analysis is needed to establish the net benefits/losses for upstream and downstream users.

Reduced groundwater withdrawals under drip irrigation may result in lower pumping hours and potentially reduced electricity consumption as compared to flood irrigation. Due to free electricity policy, the farmers may not directly realize the money savings though reduced electricity consumption however, the state and electric utilities are likely to be benefited from the energy savings. Converting 50\% area from flood to drip will reduce the electricity consumption by $24 \%\left(7 \times 10^{6} \mathrm{Mwh}\right)$ compared to the no intervention under the high withdrawals scenario. This is almost equal to the energy produced by Nagarjuna Sagar dam (capacity $=816 \mathrm{MW}$ ), the second largest hydro-electric generation plant in Andhra Pradesh, if it were operating at its full capacity during entire year. This saving will improve the state's economy by better provision of electricity to small scale industries which will generate yet another source of income. Estimated average energy consumption was $5870 \mathrm{kwh} / \mathrm{year} /$ tube well ( $5 \mathrm{kwh} / \mathrm{h} /$ tube well) under the high withdrawals and business-asusual option; this is a conservative estimate considering the reported value of $6000 \mathrm{kwh} / \mathrm{year} /$ tube well under present conditions (Kimmich, 2013). Assumption of similar lift heads, pumping hours and flow rates in the watershed and the state are the likely reason for this conservative estimate of future energy consumption as compared to the reported literature value for present energy consumption. Reduced energy consumption under drip irrigation could save $\$ 690$ million to the state, which is $35 \%$ of the agricultural power subsidy during 2012-2013. These savings are likely to be higher because our energy savings estimates are conservative. Reduction in energy consumption would also reduce the carbon dioxide emissions by $6000 \mathrm{Mt}$ annually; assuming $0.85 \mathrm{~kg} \mathrm{Co}_{2} / \mathrm{kwh}$ of electricity generation (Raghuvanshi et al., 2006). Reduced power subsidy (in addition to drip) and subsequent reduction in energy consumption would further reduce the carbon footprint of groundwater irrigation. Most of the pumps in Andhra Pradesh and other hard rock regions with power subsidy are electric powered therefore proportional reductions in carbon emissions due to subsidy reduction $(\approx 50 \%)$ and drip irrigation $(\approx 28 \%)$ would significantly reduce the carbon foot print of the region as well as the Indian irrigated agriculture. Overall, adoption of the demand and supply management options such as drip irrigation would result in economically and environmentally sustainable water-food-energy nexus in the future.

\section{Conclusions}

Our study shows that current growth in irrigation withdrawals will lead to overall reduced water sustainability with increased food production losses and energy footprint of irrigated agriculture. Well drying and crop failure are likely to increase in response to increased future groundwater withdrawals in the study watershed and beyond with similar conditions. Earlier and more frequent well drying will likely increase crop losses which is one of the reasons for farmer's emotional distress in the region. The dry season fresh market vegetables, a significant source of farmer's income, are especially vulnerable to damage from declining water table. Other associated adverse impact includes reduced surface flows to regional rivers such as Krishna and the Godavari. The reduction in river flows will negatively affect the domestic, agricultural and industrial water supply as well as the hydropower generation in many states and downstream ecolo- gies. The Krishna River (catchment $=26$ million ha) has already been experiencing decreased flows (Bouwer et al., 2006) with the 2015-2016 flows reaching an alarming level of only $10 \%$ of the historic average flows. The predicted worsening of flows is likely to damage not only dependent ecosystem but also the water supply and power generation. Reduced water availability and higher (27-108\%) energy demands of existing irrigation pumps due to declining groundwater levels would create a vicious water-food-energy nexus in the region under business-as-usual management.

Free electricity policy is the primary cause of water wastage and groundwater declines, however, removal of the subsidy may not be a solution because millions of farmers depend on it. Partial reduction in power subsidy along with flood to drip irrigation conversion and water storage can potentially create a winwin situation for all including farmers, electric utility companies, state and the environment. Partial transfer of state power subsidy funds ( $\$ 6$ billion in 3-6 years) to drip irrigation and water storage can help increase the agricultural production and water use efficiency without incurring additional economic burden to the state. In addition to being beneficial to both the state and farmers, this combination of management strategy can support up to $50 \%$ more irrigated areas in the future as well as mitigate the well drying during drought or consecutive average/below average rainfall years. Increased water availability, farm income (\$987-\$1397 during drought years), and reduced energy (24\%; $7 \times 10^{6} \mathrm{Mwh}$ ) and carbon footprints (6000 Mt/year) are likely to result in more sustainable water-food-energy nexus under these management options in the future. This study used a field-verified integrated model to predict reductions in groundwater availability and design both supply and demand management solutions to reverse the declining groundwater and surface water levels and flows and help achieve policy changes for a sustainable water-food-energy-nexus. By virtue of its reliability and resilience to climatic variability, groundwater-based irrigation is critical for the livelihood of millions of small and medium scale farmers in the semi-arid hard rock aquifer region which occupies almost two-thirds of India (240 million ha). Future increases in intense rainfall events under a changed climate may further exacerbate water availability by decreasing groundwater recharge. Future integrated modeling studies should develop and verify farmer-friendly and drought-resistant management strategies under changed climatic scenarios and land use settings in the larger hard rock aquifer systems that cover almost $20 \%$ of global land areas.

\section{Acknowledgments}

We would like to thank Directorate of Economics and Statistics (DES), Groundwater Department of the state of Telangana (former Andhra Pradesh) and National Geophysical Research Institute (NGRI), Hyderabad for providing useful hydro-geologic information of the study region.

\section{References}

Abbott, M.B., Bathurst, J.C., Cunge, J.A., O’Connell, P.E., Rasmussen, J., 1986a. An introduction to the European Hydrological System-Syst'emeHydrologique Europeen, 'SHE' 1 . History and philosophy of a physically-based, distributed modeling system. J. Hydrol. 87 (1), 45-59.

Abbott, M.B., Bathurst, J.C., Cunge, J.A., O'Connel, P.E., Rasmussen, J., 1986b. An introduction to the European Hydrological System - Système Hydrologique Européen "SHE" 2: structure of a physically based distributed modelling system. J. Hydrol. 87 (1), 61-77.

Adamowski, J., Chan, H.F., Prasher, S.O., Sharda, V.N., 2012. Comparison of multivariate adaptive regression splines with coupled wavelet transform artificial neural networks for runoff forecasting in Himalayan micro- watersheds with limited data. J. Hydroinform. 14 (3), 731-744.

Addams, L., Boccaletti, G., Kerlin, M., Stuchtey, M., 2009. Charting Our Water Future: Economic Frameworks to Inform Decision-Making. McKinsey \& 
Company, New York Available at: http://www.mckinsey.com/client_service/ sustainability/latest_thinking/charting_our_water_future. Accessed on 12 May 2015.

Al-Khafaf, S., Wierenga, P.J., Williams, B.C., 1978. Evaporative flux from irrigated cotton as related to leaf area index, soil water and evaporative demand. Agron. J. 70 (6), 912-917.

Allen, R.G., Pereira, L.S., Raes, D., Smith, M., 1998. Crop evapotranspiration. In: FAO Irrigation and Drainage Paper 56. FAO, Rome, pp. 103-125.

Amarasinghe, U.A., Shah, T., Turral, H., Anand, B.K., 2007. India's Water Future for 2025-2050: Business- as- usual Scenario and Deviations. International Water Management Institute, Colombo, Sri Lanka Available at: http://www. iwmi.cgiar.org/Publications/IWMI_Research_Reports/PDF/PUB123/RR123.pdf. Accessed July 24, 2015.

AQUASTAT, 2010. Water Resources Development and Management Service. Food and Agriculture Organization of the United Nations, Rome, Italy Available at: http: //www.fao.org/nr/water/aquastat/main/index.stm. Accessed on 27 March 2015.

Badiani, R., Jessoe, K., 2013. The impact of electricity subsidies on groundwater extraction and agricultural production. Working paper, University of California at Davis Available at: http://economics.ucdavis.edu/events/papers/Jessoe51.pdf. Accessed on 18 May 2017.

Bland, W.L., 1993. Cotton and soybean root system growth in three soil temperature regimes'. Agron. J. 85 (4), 906-911.

Bouma, J.A., Biggs, T.W., Bouwer, L.M., 2011. The downstream externalities of harvesting rainwater in semi-arid watersheds: an Indian case study. Agric. Water Manage. 98 (7), 1162-1170.

Bouwer, L.M., Aerts, J.C.J.H., Droogers, P., Dolman, A.J., 2006. Detecting the long-term impacts from climate variability and increasing water consumption on runoff in the Krishna river basin (India). Hydrol. Earth Syst. Sci. Discuss. 3 (4), 1249-1280.

Briscoe, J., Malik, R.P.S., 2006. India's Water Economy: Bracing for a Turbulent Future. Oxford University Press, New Delhi.

Central Ground Water Board (CGWB), 2007a. Groundwater Information, Medak District, Andhra Pradesh. Government of India, Faridabad.

Central Ground Water Board (CGWB), 2007b. Groundwater Information, Nalgonda District, Andhra Pradesh. Government of India, Faridabad.

Central Ground Water Board (CGWB), 2007c. Groundwater Information, Rangareddy District, Andhra Pradesh. Government of India, Faridabad.

Central Ground Water Board (CGWB), 2011. Dynamic Ground Water Resources of India (As on March 2009). Ministry of Water Resources, Government of India, Faridabad.

Central Ground Water Board (CGWB), 2014. Dynamic Ground Water Resources of India (As on 31st March 2011). Ministry of Water Resources, Government of India, Faridabad.

Demetriou, C., Punthakey, J.F., 1999. Evaluating sustainable groundwater management options using MIKE SHE integrated hydrogeological modeling package. Environ. Modell. Softw. 14 (2), 129-140.

Dewandel, B., Perrin, J., Ahmed, S., Aulong, S., Hrkal, Z., Lachassagne, P., Samad, M., Massuel, S., 2010. Development of a tool for managing groundwater resources in semi-arid hard rock regions: application to a rural watershed in South India. Hydrol. Processes 24 (19), 2784-2797. http://dx.doi.org/10.1002/hyp.7696.

Dewandel, B., Maréchal, J.C., Lachassagne, P., Wyns, R., Krishnamurthy, N.S., 2006. A conceptual hydrogeological model of hard rock aquifers structure and hydrodynamic parameters controlled by a multiphase weathering. J. Hydrol. 330 (1), 260-284.

Directorate of Economics and Statistics (DES), 2004. 3rd Minor Irrigation Census, 2000-2001. Government of Andhra Pradesh, Hyderabad.

Directorate of Economics and Statistics (DES), 2013a. 4th Minor Irrigation Census 2006-2007 (Final Report). Government of Andhra Pradesh, Hyderabad.

Directorate of Economics and Statistics (DES), 2013b. Season and Crop Report Andhra Pradesh 2012-13. Government of Andhra Pradesh, Hyderabad.

Dubash, N.K., 2007. The electricity-groundwater conundrum: Case for a political solution to a political problem. Economic and Political Weekly 42 (52), 45-55.

Famiglietti, J.S., 2014. The global groundwater crisis. Nat. Clim. Change 4 (11), 945948. http://dx.doi.org/10.1038/nclimate2425.

Feyen, L., Vazquez, R., Christiaens, K., Sels, O., Feyen, J., 2000. Application of a distributed physically-based hydrological model to a medium size catchment. Hydrol. Earth Syst. Sci. Discuss. 4 (1), 47-63.

Foster, S., 2012. Hard-rock aquifers in tropical regions: using science to inform development and management policy. Hydrogeology Journal 20 (4), 659-672.

Garg, K.K., Karlberg, L., Barron, J., Wani, S.P., Rockstrom, J., 2012. Assessing impacts of agricultural water interventions in the Kothapally watershed, Southern India. Hydrol. Processes 26 (3), 387-404.

George, B.A., Malano, H.M., Khan, A.R., Gaur, A., Davidson, B., 2009. Urban water supply strategies for Hyderabad, India - future scenarios. Environ. Model. Assess. 14 (6), 691-704.

Gleeson, T., Wada, Y., Bierkens, M.F.P., vanBeek, L.P.H., 2012. Water balance of global aquifers revealed by groundwater footprint. Nature 488 (7410), 197-200. http:// dx.doi.org/10.1038/nature11295.

Government of Telanagana, 2016. Reinventing Telangana The way forward Socio Economic Outlook 2016. Planning Department Available at http://www. telanganalegislature.org.in/documents/10656/19317/SES+Outlook+2016.pdf/ aed9e53a-2977-45a2-b658-2145d4c3e583, accessed on 14 December 2016.

Government of India, 2014. Annual (2013-14) Report on the Working of State Power Utilities \& Electricity Departments. Planning Commission (Power and Energy Division), New Delhi.
Graham, D.N., Butts, M.B., 2005. Flexible, integrated watershed modelling with MIKE SHE. In: Singh, V.P., Frevert, D.K. (Eds.), Watershed Models. CRC Press, pp. 245-272. ISBN: 0849336090.

Gruere, G.P., Mehta-Bhatt, P., Sengipta, D., 2008. Bt Cotton and Farmer Suicides in India, Reviewing the Evidence. Environment and Production Technology Division, IFPRI, Washington DC, USA IFPRI Discussion Paper \# 00808.

Guihéneuf, N., Boisson, A., Bour, O., Dewandel, B., Perrin, J., Dausse, A., Maréchal, J.C., 2014. Groundwater flows in weathered crystalline rocks: Impact of piezometric variations and depth-dependent fracture connectivity. J. Hydrol. 511, 320-334.

Gupta, H.V., Sorooshian, S., Yapo, P.O., 1999. Status of automatic calibration for hydrologic models: comparison with multilevel expert calibration. J. Hydrologic Eng. 4 (2), 135-143.

Havnø, K., Madsen, M.N., Dørge, J., 1995. MIKE 11 - a generalised river modelling package. In: Singh, V.P. (Ed.), Computer Models of Watershed Hydrology. Water Resources Publications, Colorado, USA, pp. 809-846.

Im, S., Kim, H., Kim, C., Jang, C., 2009. Assessing the impacts of land use changes on watershed hydrology using MIKE SHE. Environmental Geology 57 (1), 231-239. http://dx.doi.org/10.1007/s00254-008-1303-3.

Jaber, F.H., Shukla, S., 2012. MIKE SHE: model use, calibration, and validation. Trans, ASABE 55 (4), 1479-1489.

Jaber, F.H., Shukla, S., 2004. Simulating water dynamics in agricultural stormwater impoundments for irrigation water supply. Trans. ASAE 47 (5), 1465-1476.

Jones, J.P., Sudicky, E.A., McLaren, R.G., 2008. Application of a fully-integrated surface-subsurface flow model at the watershed-scale: a case study. Water Resour. Res. 44 (3), W03407. http://dx.doi.org/10.1029/2006WR005603.

Kakhandaki, S.H., Padmakumari, O., Madhusudhan, M.S., Ramappa, K.T., 2012. Study on cost economics of drip and micro sprinkler irrigation systems for tomato crop. Int. J. Agric. Eng. 5 (1), 95-97.

Killada, N.V., Badiger, S., Thomas, B.K., 2012. Flood in Krishna basin Institurional responses to flood regulation, published. In: Prasad, E., Joy, K.J., Paranjape, S., Vispute, S. (Eds.), Agony of Floods: Flood Induced Water Conflicts in India.

Kimmich, C., 2013. Incentives for energy-efficient irrigation: Empirical evidence of technology adoption in Andhra Pradesh, India. Energy Sustainable Dev. 17 (3), 261-269.

Kondolf, G.M., Gao, Y., Annandale, G.W., Morris, G.L., Jiang, E., Zhang, J., Cao, Y., Carling, P., Fu, K., Guo, Q., Hotchkiss, R., 2014. Sustainable sediment management in reservoirs and regulated rivers: experiences from five continents. Earth's Future 2 (5), 256-280.

Konikow, L.F., Kendy, E., 2005. Groundwater depletion: a global problem. Hydrogeol. J. 13 (1), 317-320. http://dx.doi.org/10.1007/s10040-004-0411-8.

Kumar, M.D., Patel, A., Ravindranath, R., Singh, O.P., 2008. Chasing a mirage: water harvesting and artificial recharge in naturally water-scarce regions. Economic and Political Weekly 61-71.

Kumar, M.D., Scott, C.A., Singh, O.P., 2011. Inducing the shift from flat-rate or free agricultural power to metered supply: Implications for groundwater depletion and power sector viability in India. J. Hydrol. 409 (1), 382-394.

Limaye, S.D., 2010. Groundwater development and management in the Deccan Traps (basalts) of western India. Hydrogeol. J. 18 (3), 543-558.

Maréchal, J.C., Dewandel, B., Ahmed, S., Galeazzi, L., Zaidi, F.K., 2006. Combined estimation of specific yield and natural recharge in a semi-arid groundwater basin with irrigated agriculture. J. Hydrol. 329 (1), 281-293. http://dx.doi.org/10.1016/ j.jhydrol.2006.02.022.

Massuel, S., George, B., Gaur, A., Nune, R., 2007. Groundwater modelling for sustainable resource management in the Musi catchment, India. In: Proceedings, International Congress on Modelling and Simulation, vol. 10. Christchurch, New Zealand, pp. 1429-1435.

Massuel, S., Perrin, J., Mascre, C., Mohamed, W., Boisson, A., Ahmed, S., 2014. Managed aquifer recharge in South India: What to expect from small percolation tanks in hard rock? J. Hydrol. 512, 157-167.

McLaughlin, D., Kinzelbach, W., 2015. Food security and sustainable resource management. Water Resour. Res. 51 (7), 4966-4985.

Mohan, S., Arumugam, N., 1994. Crop coefficients of major crops in South India. J. Agric. Water Manage. 26 (1), 67-80.

Mohanty, B.B., Shroff, S., 2004. Farmers' suicides in Maharashtra. Economic and Political Weekly 39 (52), 5599-5606.

Moriasi, D.N., Arnold, J.G., Van Liew, M.W., Bingner, R.L., Harmel, R.D., Veith, T.L., 2007. Model evaluation guidelines for systematic quantification of accuracy in watershed simulations. Trans. ASABE 50 (3), 885-900.

Narayanamoorthy, A., 2004. Drip irrigation in India: can it solve water scarcity? Water Policy 6, 117-130.

Nash, J.E., Sutcliffe, J.V., 1970. River flow forecasting through conceptual models: Part 1. A discussion of principles. J. Hydrol. 10 (3), 282-290.

NCRB. National Crime Reports Bureau, India.

Perrin, J., Ferrant, S., Massuel, S., Dewandel, B., Maréchal, J.C., Aulong, S., Ahmed, S., 2012. Assessing water availability in a semi-arid watershed of southern India using a semi-distributed model. J. Hydrol. 460, 143-155.

Qureshi, A.S., 2014. Reducing carbon emissions through improved irrigation management: a case study from Pakistan. Irrig. Drain. 63 (1), 132-138.

Raghuvanshi, S.P., Chandra, A., Raghav, A.K., 2006. Carbon dioxide emissions from coal based power generation in India. Energy Convers. Manage. 47 (4), 427-441.

Rao, P.N., Suri, K.C., 2006. Dimensions of agrarian distress in Andhra Pradesh. Economic and Political Weekly 41 (16), 1546-1552.

Richts, A., Struckmeier, W.F., Zaepke, M., 2011. WHYMAP and the groundwater resources map of the world 1: 25,000,000. In: Sustaining Groundwater Resources. Springer, Netherlands, pp. 159-173. 
Rodell, M., Velicogna, I., Famiglietti, J.S., 2009. Satellite-based estimates of groundwater depletion in India. Nature 460 (7258), 999-1002. http://dx.doi.org/10. 1038/nature08238.

Schaap, M.G., Leij, F.J., van Genuchten, M.Th., 2001. ROSETTA: a computer program for estimating soil hydraulic parameters with hierarchical pedotransfer functions. J. Hydrol 251, 163-176.

Sharmila, S., Joseph, S., Sahai, A.K., Abhilash, S., Chattopadhyay., R., 2015. Future projection of Indian summer monsoon variability under climate change scenario: An assessment from CMIP5 climate models. Global and Planetary Change 124, $62-78$.

Shah, T., 2008. India's master plan for groundwater recharge: an assessment and some suggestions for revision. Economic and political weekly 43 (51), 41-49.

Shah, T., 2009. Climate change and groundwater: India opportunities for mitigation and adaptation. Environ. Res. Lett. 4 (3), 035005.

Shah, T., 2012. Community response to aquifer development: distinct patterns in India's alluvial and hard rock aquifer areas. Irrig. Drain. 61 (S1), 14-25.

Shah, T., Burke, J., Villholth, K., 2007. Groundwater: a global assessment of scale and significance. In: Molden, D. (Ed.), Water For Food, Water for Life. Earthscan, London, UK and IWMI, Colombo, Sri Lanka, pp. 395-423.

Shah, T., Bhatt, S., Shah, R.K., Talati, J., 2008. Groundwater governance through electricity supply management: assessing an innovative intervention in Gujarat, western India. Agric. Water Manage. 95 (11), 1233-1242.

Shah, T., Scott, C., Kishore, A., Sharma, A., 2004. Energy-irrigation Nexus in South Asia: Improving Groundwater Conservation and Power Sector Viability, Second (revised) ed. International Water Management Institute, Colombo, Sri Lanka Research Report 70.

Shiferaw, B.A., Okello, J., Reddy, R.V., 2009. Adoption and adaptation of natural resource management innovations in smallholder agriculture: reflections on key lessons and best practices. Environ. Dev. Sustainability 11 (3), 601-619.

Singhal, B.B.B. 1997. Hydrogeological characteristics of the Deccan Trap formation in India. Hard Rock Hydrosystems IAHS Publ. no. 241, 75-80.

Singhal, B.B.S., 2007. Nature of hard rock aquifers: Hydrogeological uncertainties and ambiguities. In: Ahmed, S., Jaykumar, R., Saliah, A. (Eds.), Groundwater Dynamics in Hard Rock Aquifers Sustainable Management and Optimal Monitoring Network Design. Capital Publishing Company, New Delhi, India, p. 250. ISBN-81-85589-25-9.

Sishodia, R.P., Shukla, S., Graham, W.D., Wani, S.P., Garg, K.K., 2016. Bi-decadal groundwater level trends in a semi-arid south Indian region: Declines, causes and management. J. Hydrol. 8, 43-58.

Sivanappan, R.K., 1994. Prospects of Micro-irrigation in India. Irrig. Drain. Syst. (8) 49-58.

Sphere India, 2009. Situation Report, 5th October 2009, Andhra Pradesh Floods Available at http://reliefweb.int/sites/reliefweb.int/files/resources/ F1BE94903C26C4C6852576460063E054-Full_Report.pdf. Last accessed on 19th February 2016.
Sreedevi, T.K., Shiferaw, B., Wani, S.P., 2004. Adarsha Watershed in Kothapally Understanding the Drivers of Higher Impact: Global Theme on Agroecosystems Report no. 10.

Stoll, S., Hendricks Franssen, H.J., Butts, M., Kinzelbach, W., 2011. Analysis of the impact of climate change on groundwater related hydrological fluxes: a multimodel approach including different downscaling methods. Hydrol. Earth Syst. Sci. 15 (1), 21-38. http://dx.doi.org/10.5194/hess-15-21-2011.

Surinaidu, L., Bacon, C.G.D., Pavelic, P., 2013. Agricultural groundwater management in the Upper Bhima Basin, India: current status and future scenarios. Hydrol. Earth Syst. Sci. 17 (2), 507-517.

Tilman, D., Balzer, C., Hill, J., Befort, B.L., 2011. Global food demand and the sustainable intensification of agriculture. Proc. Natl. Acad. Sci. 108 (50), 20260-20264.

Van Genuchten, M.T., 1980. A closed-form equation for predicting the hydraulic conductivity of unsaturated soils. Soil Sci. Soc. Am. J. 44 (5), 892-898.

Vansteenkiste, T., Tavakoli, M., Ntegeka, V., Willems, P., De Smedt, F., Batelaan, O., 2013. Climate change impact on river flows and catchment hydrology: a comparison of two spatially distributed models. Hydrol. Process. 27 (25), 3649-3662.

Varalakshmi, V., Venkateswara Ra, B., SuriNaidu,, L., Tejaswini., M., 2012. Groundwater Flow Modeling of a Hard Rock Aquifer: Case Study. Journal of Hydrologic Engineering, 19 (5), 877-886.

Wada, Y., van Beek, L.P.H., van Kempen, C.M., Reckman, J.W.T.M., Vasak, S., Bierkens, M.F.P., 2010. Global depletion of groundwater resources. Geophys. Res. Lett. 37 (20), L20402. http://dx.doi.org/10.1029/2010GL044571.

Wani, S.P., Singh, H.P., Sreedevi, T.K., Pathak, P., Rego, T.J., Shiferaw, B., Iyer, S.R. 2003. Farmer-participatory integrated watershed management: Adarsha watershed, Kothapally India-an innovative and upscalable approach. J. SAT Agric. Res. 2 (1), 1-27.

Wen, F., Chen, X., 2006. Evaluation of the impact of groundwater irrigation on streamflow in Nebraska. J. Hydrol. 327 (3), 603-617. http://dx.doi.org/10.1016/ j.jhydrol.2005.12.016.

Wijesekara, G.N., Gupta, A., Valeo, C., Hasbani, J.G., Qiao, Y., Delaney, P., Marceau, D.J., 2012. Assessing the impact of future land-use changes on hydrological processes in the Elbow River watershed in southern Alberta, Canada. J. Hydrol. 412, 220-232.

Willmott, C.J., 1981. On the validation of models. Phys. Geogr. 2 (2), 184-194.

World Bank, 2010. Deep Wells and Prudence: Towards pragmatic Action for Addressing Groundwater Overexploitation in India Washington D.C., USA. Available at http://documents.worldbank.org/curated/en/2010/01/11899840/ deep-wells-prudence-towards-pragmatic-action-addressing-groundwateroverexploitation-india. Accessed on 24th July 2015. 